\title{
Research and Comparative Analysis of Flow Field Characteristics and Load-Independent Power Losses of Internal and External Gear Pairs
}

\author{
Qing-liang Zeng $\left(\mathbb{D},{ }^{1,2}\right.$ Zhi-yuan Sun $\mathbb{D}^{1},{ }^{1}$ Li-rong Wan ${ }^{D}$, ${ }^{1}$ Yang Yang $\mathbb{D}^{1},{ }^{1}$ \\ Han-zheng Dai $\mathbb{D}^{1}{ }^{1}$ and Zhi-kuan Yang ${ }^{1}$ \\ ${ }^{1}$ College of Mechanical and Electronic Engineering, Shandong University of Science and Technology, Qingdao 266590, China \\ ${ }^{2}$ College of Information Science and Engineering, Shandong Normal University, Jinan 250358, China
}

Correspondence should be addressed to Zhi-yuan Sun; izhysun@163.com and Yang Yang; sdkdyangyang@126.com

Received 29 August 2020; Revised 20 November 2020; Accepted 25 November 2020; Published 10 December 2020

Academic Editor: Luigi Rodino

Copyright (c) 2020 Qing-liang Zeng et al. This is an open access article distributed under the Creative Commons Attribution License, which permits unrestricted use, distribution, and reproduction in any medium, provided the original work is properly cited.

\begin{abstract}
Power loss analysis of gear transmission in a transmission system is of great significance to improve the efficiency of the power system, and load-independent power losses are an important part of the power losses of gear transmission. Based on the computational fluid dynamics (CFD) method, the hydrodynamic models of internal and external gear pairs are established. By analyzing the pressure field and the velocity field, the windage and squeezing power losses and the pressure and viscous power losses, the influence of rotation speed and tooth width on flow field characteristics, and load-independent power losses of internal gear pair are studied. In addition, we compare the flow field characteristics and the load-independent power losses between external and internal gear pairs and discuss the difference between them. The results show that the pressure and fluid velocity in the meshing area of the gear pair are greatly affected by rotation speed and tooth width, and the load-independent power losses increase with the increase of rotation speed and tooth width. At the same rotation speed, the transmission ratio and number of teeth, windage, and squeezing power losses of the external gear pair are smaller than those of the internal gear pair. Compared with the internal gear pair, the external gear pair has more advantages in controlling the load-independent power losses. The difference of the load-independent power losses of the two meshing modes mainly comes from the viscous power losses of the wheel gear of internal gear pair. This paper provides a basis for the selection of the gear meshing mode and the analysis of load-independent power losses of the transmission system.
\end{abstract}

\section{Introduction}

The transmission system plays a pivotal role in transportation, aviation, energy, and other industries. As one of the important components of the transmission system, the efficiency has been paid more and more attention in its design process, and the demand for high-efficiency transmission is also increasing [1]. The power losses of gear transmission in the transmission can be classified into loaddependent and load-independent power losses with reference to their dependence from the transmitted load [2]. Furthermore, the total power losses can be divided into loaddependent and load-independent power losses of the gears
$\left(P_{\mathrm{VG}}\right.$ and $\left.P_{\mathrm{VG} 0}\right)$ and bearings $\left(P_{\mathrm{VB}}\right.$ and $\left.P_{\mathrm{VG} 0}\right)$, load-independent power losses related to the seals $\left(P_{\mathrm{VD} 0}\right)$, and other general power losses related $\left(P_{\mathrm{VX}}\right)$, such as those of clutches or synchronizers.

$$
P_{\mathrm{V}}=P_{\mathrm{VG}}+P_{\mathrm{VG} 0}+P_{\mathrm{VB}}+P_{\mathrm{VB} 0}+P_{\mathrm{VD} 0}+P_{\mathrm{VX}}
$$

This paper is focused on the load-independent power losses of gears, which can be further divided into churning $\left(P_{\mathrm{VG}, C}\right)$, windage $\left(P_{\mathrm{VG}, W}\right)$, and squeezing power losses $\left(P_{\mathrm{VG} 0, S}\right)[3]$. The churning power losses are mainly related to the pressure and viscous effects of the oil-gas mixture on the moving gears, which are greatly affected by the lubricant 
quantity and properties and the working state of the gears. The windage power losses are similar to churn power losses in essence, which are only related to the effect of a single fluid (air or oil) to the moving gears. When a pair of gears are engaged, the increase and decrease of the meshing clearance will produce a high-pressure area and low-pressure area in the meshing area and separation area, and then, oil squeezing will occur. The fluid will produce pressure gradients and additional axial flows, and a pair of gears will produce additional power losses, that is, squeezing power losses.

$$
P_{\mathrm{VG} 0}=P_{\mathrm{VG} 0, C}+P_{\mathrm{VG} 0, W}+P_{\mathrm{VG} 0, S} \cdot
$$

In the early stage, international scholars have carried out a lot of theoretical and experimental research on the load-independent power losses of the transmission. Mauz [4] studied the load-independent power losses of the transmission and proposed what is considered to be the most complete empirical formula, but its scope of application is still limited. Boness [5] used a smooth disk instead of a cylindrical gear, experimentally studied the influence of disk diameter and lubricating oil immersion depth on gear resistance moment, and obtained the empirical formula of gear resistance moment. Hóhn et al. [6] concluded through experimental research that reducing the oil level of the gearbox can reduce the resistance moment and churning power losses, but the temperature of the gearbox will increase. Seetharaman et al. $[7,8]$ hypothesized that the load-independent losses are mainly composed of two parts. The first part is the loss caused by the gear rotation agitating oil, and the second part is the loss caused by the continuous oil squeezing in the gear meshing area. Changenet et al. [9, 10] analyzed several established formulas for churning power losses. It was found that the validity of the formulas depended on the Reynolds number, and a new theoretical model was proposed. Schaffner et al. [11] established a rotating multibody model of automobile manual transmission. It was found that, with the increase of input speed, the churning losses of gears increased, while with the increase of oil temperature, the churning losses decreased. Neurouth et al. [12] measured the churning losses of a single spur gear and a single helical gear by experiment, analyzed the influence of the flange on the churning losses in gearbox, and proposed a method to determine the position of the flange.

All the abovementioned research studies were based on theoretical calculation or experimental test, and the proposed models were obtained by fitting experimental measurements under specific conditions, which greatly limited its scope of application. With the development of computeraided analysis technology, the computational fluid dynamics method has become a more reliable and effective method to analyze the load-independent power losses of gears. Gorla $[13,14]$ and Concli et al. [15-17] established the models of windage power losses and churning power losses of a single spur gear and gear pair, analyzed the influence of geometric parameters and working parameters on power losses, and verified the validity of the models with experiments. Liang et al. $[18,19]$ used the CFD method to study the load- independent power losses of a spur gear and helical gear under different working conditions. Liu et al. [20] established a CFD model of a single-stage gearbox, and the analysis results showed that the simulation and experimental data had good consistency, indicating that the CFD method based on the finite volume method was an effective tool for simulating the distribution of lubricating oil and the loadindependent power losses in the gearbox. Hu et al. [21] studied the influence of dynamic motion of a gear pair under splash lubrication on internal flow field and churning power losses, and the results showed that dynamic motion of the gear pair had a significant influence on churning power losses and oil supply in the gear meshing area, and even the gear pair may be in a state of loss of lubrication. Dai et al. [22] analyzed the windage losses of a single-face gear with or without shroud and the influence of face gear speed on windage losses and concluded that shroud can effectively reduce windage power losses. Concli et al. $[23,24]$ used a new automatic mesh-partitioning strategy to extend the applicability of CFD simulation in the simulation analysis of internal lubrication and churning power losses of a planetary gear pair under the condition of retaining the basic structure of the planetary gear pair. Mo et al. [25] established the CFD model for the coast flank and the drive flank injection lubrication on the asymmetric helical gear and analyzed the influence of rotation speed and spray velocities on oil volume fraction and pressure under different injection modes. The research results of many scholars mentioned above indicate that the CFD method is an effective method to analyze and study the load-independent power losses of the gearbox, which has been verified by experimental results.

Most of the existing research studies are focused on the load-independent power losses of a single gear and an external gear pair, and a few research studies on the load-independent power losses of a planetary gear pair are mainly focused on the working condition with a fixed ring gear. There is little research on an internal gear pair, and there is no analysis of the influence of external and internal meshing modes on the load-independent power losses, which greatly limit the establishment and improvement of the model of load-independent power losses. Therefore, in this paper, the influence of rotation speed and tooth width on the flow field characteristics and loaddependent power losses of an internal gear pair is studied by using the computational fluid dynamics method. The effects of internal and external meshing modes on flow field characteristics and load-independent power losses are compared, and the differences among them are discussed.

\section{Gear Pair Computational Fluid Dynamics Model}

2.1. Fluid Computational Domain Model of the Gear Pair. According to the structural size of a transmission, the computational domain size is determined to be $\phi 160 \mathrm{~mm} \times 80 \mathrm{~mm}$. The external and internal gear pairs with the same transmission ratio and number of teeth are selected. The geometric parameters of gear pairs are shown in Table 1. The meshing clearance of a normal meshing gear pair is very small, which is not conducive to the mesh of the 
TABLE 1: Geometric parameters of gears.

\begin{tabular}{|c|c|c|c|c|c|c|c|}
\hline Gear pair & Gear & $\begin{array}{c}\text { Number of } \\
\text { teeth } z\end{array}$ & $\begin{array}{c}\text { Module } m \\
(\mathrm{~mm})\end{array}$ & $\begin{array}{c}\text { Pressure angle } \alpha_{n} \\
\text { (deg.) }\end{array}$ & $\begin{array}{l}\text { Tooth width } b \\
(\mathrm{~mm})\end{array}$ & $\begin{array}{c}\text { Tip diameter } d_{a} \\
(\mathrm{~mm})\end{array}$ & $\begin{array}{c}\text { Center distance a } \\
(\mathrm{mm})\end{array}$ \\
\hline External gear & Pinion & 36 & 1 & 20 & 15 & 38 & \multirow{2}{*}{72} \\
\hline pair & Wheel & 108 & 1 & 20 & 15 & 106 & \\
\hline Internal gear & Pinion & 36 & 1 & 20 & 15 & 38 & \multirow{2}{*}{36} \\
\hline pair & Wheel & 108 & 1 & 20 & 15 & 110 & \\
\hline
\end{tabular}

fluid computational domain. In addition, in order to simulate the meshing motion of the gear pair, ensure the continuity of the computational domain, and prevent the mesh distortion in the meshing area caused by too small meshing clearance, the model of the gear pair must be simplified to a certain extent $[14,26,27]$.

At present, common simplified processing methods include the gear-separation method, tooth-face-moving method, cutting-tooth method, and nontooth method [28]. The basic tooth structure of gears is changed by both the cutting-tooth method and the nontooth method, so that the squeezing losses cannot be accurately simulated. Although the gear-separation method retains the complete structure of gear teeth, it increases the center distance of the gear pair and changes the installation position of gears, which is limited in engineering practice. The relative position of gears is not changed by the tooth-face-moving method, but the tooth thickness is reduced appropriately to increase the meshing clearance, so as to facilitate the meshing of the fluid computational domain. The tooth-face-moving method not only does not change the gear installation position but also retains the basic structure of the gear teeth, which is close to the real situation and has good engineering applicability. Therefore, this paper adopts the tooth-face-moving method to simplify the processing of gear pairs. Fluid computational domains of gear pairs are extracted and simplified, as shown in Figure 1.

For the computational fluid dynamics simulation of gear pairs, the dynamic mesh approach is used, unstructured tetrahedron elements are used to mesh the flow field, and meshes locally encrypted near the gear teeth, as shown in Figures 2 and 3. In the process of iterative calculation, the mesh changes due to the boundary movement. The spring-based smoothing method and local cell remeshing method are used to update the mesh. In the spring-based smoothing method, mesh edges are idealized as springs connected between nodes. Before moving, the spring system equivalent to the initial grid spacing is in equilibrium. After the displacement of the grid boundary nodes, a force proportional to the displacement will be generated. The force is calculated by Hooke's law. This force will destroy the original balance of the spring system, but under the action of external force, the spring system will be adjusted to a new position to achieve balance.

For an unstructured mesh area, the smoothing method can be used to update the mesh. However, if the moving boundary displacement is too large, the smoothing method may lead to the degradation of mesh quality and even the appearance of a negative volume mesh, leading to the divergence or termination of the calculation. The local cell remeshing method will concentrate the meshes with

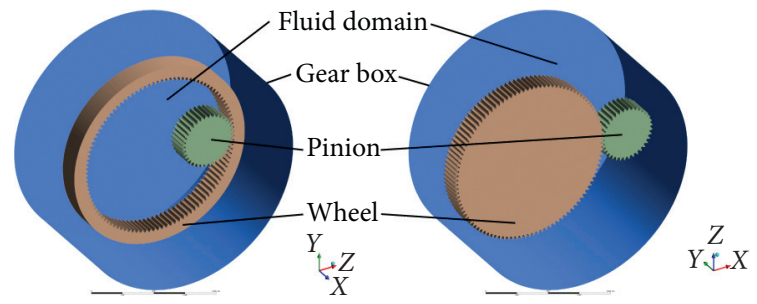

Figure 1: Simplified computational domains of internal and external gear pairs.

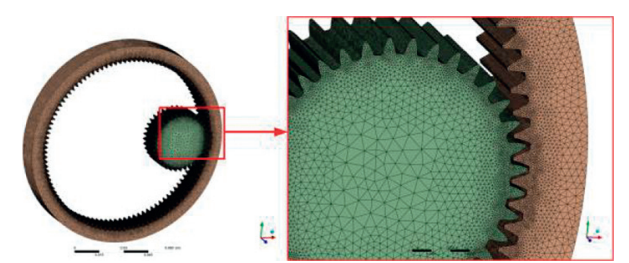

Figure 2: Computational domain grid nodes on the surface of an internal gear pair.

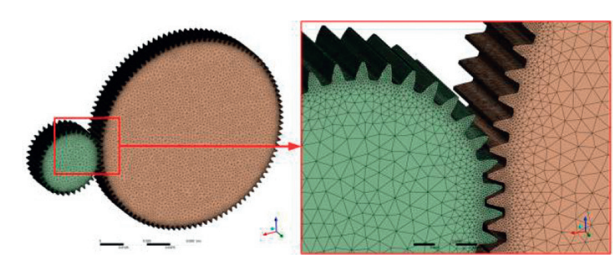

FIgURE 3: Computational domain grid nodes on the surface of an external gear pair.

excessive distortion rate or excessive size change for local mesh redivision and, then, replace the old mesh with the new mesh which meets the requirements.

\subsection{Governing Equations of the Fluid Computational Domain} for the Gear Pair. The governing equations of computational fluid dynamics calculations are the Navier-Stokes equations. The Navier-Stokes equations include the mass conservation equation and the momentum conservation equation, which are as follows:

$$
\begin{aligned}
\frac{\partial \rho}{\partial t}+\frac{\partial}{\partial x_{i}}\left(\rho u_{i}\right)= & 0 \\
\frac{\partial}{\partial t}\left(\rho u_{i}\right)+\frac{\partial}{\partial x_{j}}\left(\rho u_{i} u_{j}\right)= & -\frac{\partial p}{\partial x_{i}}+\frac{\partial}{\partial x_{j}}\left[\mu\left(\frac{\partial u_{i}}{\partial x_{j}}+\frac{\partial u_{j}}{\partial x_{i}}\right)\right] \\
& +\frac{\partial}{\partial x_{j}}\left(-\rho u_{i}^{\prime} u_{j}^{\prime}\right)+\rho f_{i},
\end{aligned}
$$


where $i, j=1,2,3$ denote three-dimensional flow, $x_{i}$ is the Cartesian coordinate, $u_{i}$ is the velocity component, $\rho$ is the density, $p$ is the pressure, $\mu$ is the viscosity, $f_{i}$ is the external force, and $-\rho u_{i} u_{j}$ is the Reynolds stress tensor.

The energy conservation equation is not considered because under the assumption that the lubricating oil is an incompressible fluid, the thermal influences can be neglected in no-load operating conditions [13].

If the Navier-Stokes equations are solved directly, it will consume a lot of computing resources, and it is difficult to be widely used in engineering. In order to overcome this problem, Reynolds [20] reduced the Reynolds-averaged Navier-Stokes (RANS) equations to deal with the turbulent fluctuation term in time. In these equations, the flow quantities in the conservation equations are divided into a time-weighted average term and an oscillating term. The oscillating term is known as the Reynolds stress tensor, and it is unknown, so it is necessary to introduce the turbulence model to solve the equations.

2.3. Turbulence Model in the Fluid Computational Domain of the Gear Pair. Boussinesq tried to find a closed form of equation (4) by introducing the concept of eddy viscosity. The Boussinesq vortex-viscosity hypothesis was used to calculate the Reynolds stress tensor:

$$
-\rho u_{i}^{\prime} u_{j}^{\prime}=\mu_{t}\left(\frac{\partial u_{i}}{\partial x_{i}}+\frac{\partial u_{j}}{\partial x_{j}}\right)-\frac{2}{3} \rho \delta_{i j} k,
$$

where $\mu_{t}$ is the eddy viscosity. Once the eddy viscosity is determined, the RANS equations can be expressed in a closed form. Over the years, different turbulence models have been developed, ranging from simple algebraic equations to $2^{\text {nd }}$-order differential equations.

During the meshing process of the gear pair, there will be large velocity fluctuation in the gear box. This kind of fluctuation makes the momentum, energy, and concentration of the fluid medium change and causes the fluctuation of material transportation. The double-equation-renormalized $k-\varepsilon$ turbulence model ( $R N G k-\varepsilon$ turbulence model) can deal with this kind of problem effectively. The $R N G k-\varepsilon$ turbulence model is based on the turbulent kinetic energy equation and the turbulent dissipation rate equation, assuming the relationship between eddy viscosity $\mu_{t}$ and turbulent kinetic energy $k$ and turbulent dissipation rate $\varepsilon$.

$$
\begin{aligned}
\frac{\partial(\rho k)}{\partial t}+\frac{\partial\left(\rho k u_{i}\right)}{\partial x_{i}}= & \frac{\partial}{\partial x_{i}}\left[\left(\alpha_{k} \mu_{e f f}\right) \frac{\partial k}{\partial x_{j}}\right]+G_{k}+G_{b}-\rho \varepsilon-Y_{M}, \\
\frac{\partial(\rho \varepsilon)}{\partial t}+\frac{\partial\left(\rho \varepsilon u_{i}\right)}{\partial x_{i}}= & \frac{\partial}{\partial x_{j}}\left[\left(\alpha_{\varepsilon} \mu_{e f f}\right) \frac{\partial \varepsilon}{\partial x_{j}}\right] \\
& +C_{1 \varepsilon} \frac{\varepsilon}{k}\left(G_{k}+C_{3 \varepsilon} G_{b}\right)-C_{2 \varepsilon} \rho \frac{\varepsilon^{2}}{k}-R .
\end{aligned}
$$

Among them,

$$
\left\{\begin{array}{l}
\mu_{e f f}=\mu+\mu_{t}, \\
\mu_{t}=C_{\mu} \rho \frac{k^{2}}{\varepsilon} .
\end{array}\right.
$$

In these equations, $G_{k}$ is the generation of the turbulent kinetic energy caused by the average velocity gradient; $G_{b}$ is the generation of the turbulent kinetic energy caused by the influence of buoyancy; $Y_{M}$ is the influence of the pulsating expansion of the compressible turbulent flow on the total dissipation rate; $C_{1 \varepsilon}, C_{2 \varepsilon}$, and $C_{3 \varepsilon}$ are empirical constants; $\alpha_{k}$ and $\alpha_{\varepsilon}$ are the reciprocal of the effective Prandtl number of turbulent kinetic energy and dissipation rate, respectively; $R$ is the improvement coefficient of model accuracy; and for high Reynolds number problems, $C_{\mu}=0.0845$.

\section{Numerical Calculation}

In this paper, because the meshing process of the gear pair is simulated and the dynamic mesh approach is used, the transient solution is adopted. Therefore, the PISO (PressureImplicit with Splitting of Operators) algorithm with high accuracy and fast convergence speed, suitable for transient and large mesh distortion problems, is selected to solve the fluid governing equations. The gradient is discretized by the Least-Squares Cell-Based method suitable for turbulence, the PRESTO (PREssure STaggering Option) scheme is used for pressure interpolation, and the Second-Order Upwind scheme is selected for momentum discretization.

Synthetic gear lubricant Klübersynth GH 6-220 is selected for the meshing transmission of the gear pair. The main physical properties of the lubricating oil are shown in Table 2.

In the process of oil-immersed lubrication of gear pair transmission, the gears will be affected by the pressure and viscosity of surrounding fluid, resulting in the resistance moment and load-independent power losses:

$$
\left\{\begin{array}{l}
\mathbf{M}=\mathbf{r} \times \mathbf{F}_{\mathbf{p}}+\mathbf{r} \times \mathbf{F}_{\mathbf{v}} \\
P=\mathbf{M} \cdot \boldsymbol{\omega}
\end{array}\right.
$$

where $P$ is the load-independent power losses; $\mathbf{M}$ is the resistance moment vector; $\mathbf{r}$ is the distance vector; $\mathbf{F}_{\mathbf{p}}$ is the pressure force vector; $\mathbf{F}_{\boldsymbol{v}}$ is the viscous force vector; and $\boldsymbol{\omega}$ is the angular velocity vector of the gear.

\section{Analysis of Flow Field Characteristics and Load-Independent Power Losses of the Gear Pair}

Taking the internal gear pair as an example, the influence of rotation speed and tooth width on the flow field characteristics and the load-independent power losses of the internal gear pair was studied by analyzing the pressure field and velocity field, windage and squeezing power losses, and pressure and viscous power losses. 
TABle 2: Main physical properties of the lubricant.

\begin{tabular}{lcc}
\hline Parameter & Symbol & $\begin{array}{c}\text { Klübersynth } \\
\text { GH6-220 }\end{array}$ \\
\hline ISO VG & - & 220 \\
Density at $15^{\circ} \mathrm{C}\left(\mathrm{kg} / \mathrm{m}^{3}\right)$ & $p$ & 1060 \\
Kinematic viscosity at $40^{\circ} \mathrm{C}\left(\mathrm{mm}^{2} / \mathrm{s}\right)$ & $v$ & 220 \\
Kinematic viscosity at $100^{\circ} \mathrm{C}\left(\mathrm{mm}^{2} / \mathrm{s}\right)$ & $v$ & 40 \\
\hline
\end{tabular}

4.1. Influence of Rotation Speed on Flow Field Characteristics and Load-Independent Power Losses. The influence of rotation speed on the flow field characteristics and the loadindependent power losses of the internal gear pair is analyzed. Figures 4-6 show the distribution and change of static pressure in the middle section of the meshing area, the tooth surface of the pinion gear, and the tooth surface of the wheel gear when rotation speed of the pinion of the internal gear pair is $2000 \mathrm{rpm}, 3000 \mathrm{rpm}$, and $4000 \mathrm{rpm}$, respectively. It can be illustrated from Figure 4 that, during the meshing process of the internal gear pair, the rapid decrease of the volume at the inlet of the meshing area leads to the rapid increase of the pressure, while at the outlet of the meshing area, the rapid increase of the volume leads to the rapid decrease of the pressure, which is also confirmed by Burberi [27]. At the same time, the local high pressure area is formed at the inlet of the meshing area, and the local low pressure area is formed at the outlet of the meshing area, as shown in Figures 5 and 6 . Also, on the tooth surface, there are two distinct pressure peaks in the middle areas of the highpressure area and the low-pressure area, and the pressure difference between the high-pressure area and the lowpressure area increases with the increase of rotation speed.

Figures 7 and 8, respectively, show the velocity nephograms of the middle section and axial section of the meshing area when rotation speed of the pinion of the internal gear pair is $2000 \mathrm{rpm}, 3000 \mathrm{rpm}$, and $4000 \mathrm{rpm}$. According to the viscous condition, the velocity of the fluid adhering to the gear is equal to the circumferential velocity, which is confirmed by the fluid velocity distribution in figures. Due to the agitation of the gears to the lubricating oil and the viscous effect of the lubricating oil on the gears, the velocity of lubricating oil increases with the increase of rotation speed, and the oil with high velocity is mainly concentrated in the meshing area and the vicinity of gear teeth. Because the inner gear in the gear pair has the outer profile, the oil velocity near the outer profile of the inner gear is higher. In the meshing area, due to the change of volume, the oil is squeezed and sucked, resulting in the high speed flow of the oil, and the velocity of the oil squeezed and sucked increases with the increase of rotation speed. The velocity disturbance at the outlet of the meshing is more significant than that at the inlet, as shown in Figure 7. In the axial direction, due to oil is squeezed and sucked in the meshing area of the gear pair, obvious axial velocity disturbance is brought, as shown in Figure 8.

It can be illustrated from Figure 9(a) that, as predicted by theory, the load-independent power losses generated by an internal gear pair are greater than the sum of the load-independent power losses generated by two single gears. In the case of full immersion lubrication, the rotation of a single gear in lubricating oil is only affected by the windage power losses, and the windage losses increase with the increase of rotation speed. In the gear pair, the reduction and expansion of the meshing area will cause the squeezing and sucking of lubricating oil. Due to the viscous effect of lubricating oil, additional power losses will be caused, that is, squeezing power losses, which increase with the increase of rotation speed. Figure 9(b) shows the proportions of windage power losses and squeezing power losses in the load-independent power losses of the internal gear pair. At different rotation speeds, the proportions of squeezing power losses in the load-independent power losses of the internal gear pair are $52.89 \%, 45.04 \%$, and $43.31 \%$, which means that the proportion of squeezing power losses in the load-independent power losses decreases with the increase of rotation speed.

Computational fluid dynamics analysis provides a new way to analyze the load-independent power losses, which are divided into pressure and viscous power losses. Figure 10 shows the variation of the pressure and viscosity losses of pinion and wheel gears in the internal gear pair with rotation speed of the pinion and their proportions in the torque losses and the power losses. The pressure and viscous torque losses of both the pinion and wheel in the internal gear pair increase with the increase of rotation speed of the pinion, which is consistent with the variation trend of pressure and velocity distribution in the computational domain, as shown in Figure 10(a). In the torque losses of the pinion of the internal gear pair, the proportion of pressure and viscous torque losses varies little with rotation speed, and the proportion of pressure torque losses is larger. The proportion of pressure torque losses increases with the increase of rotation speed, but the viscous torque losses still occupy the main position in total torque losses. Figure 10(c) shows the proportion of pressure power losses and viscous power losses in the load-independent power losses of the internal gear pair. At each rotation speed, the proportions of viscous power losses in the load-independent power losses of the internal gear pair are $61.22 \%, 57.41 \%$, and $54.55 \%$, respectively, that is, the proportion of viscous power losses in the load-independent power losses decreases with the increase of rotation speed.

\subsection{Influence of Tooth Width on Flow Field Characteristics and} Load-Independent Power Losses. The influence of the tooth width on the flow field characteristics and the load-independent power losses of the internal gear pair is analyzed. Figures 11-13 show the distribution and variation of static pressure in the middle section, the tooth surface of the pinion, and the tooth surface of the wheel in the meshing area when the rotation speed of the pinion gear is $2000 \mathrm{rpm}$ and the tooth width is $20 \mathrm{~mm}, 25 \mathrm{~mm}$, and $30 \mathrm{~mm}$, respectively. It can be illustrated from Figure 4(a) and Figure 11 that, with the increase of tooth width, the pressure difference between the high-pressure area and the lowpressure area in the meshing area increases gradually. On the 


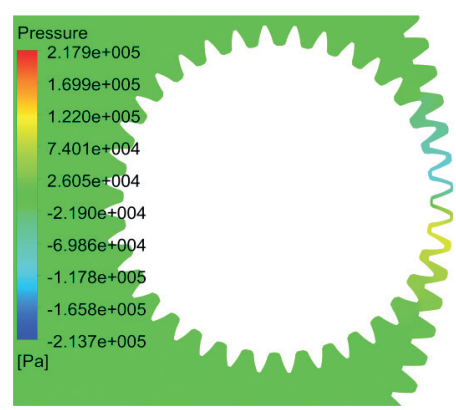

(a)

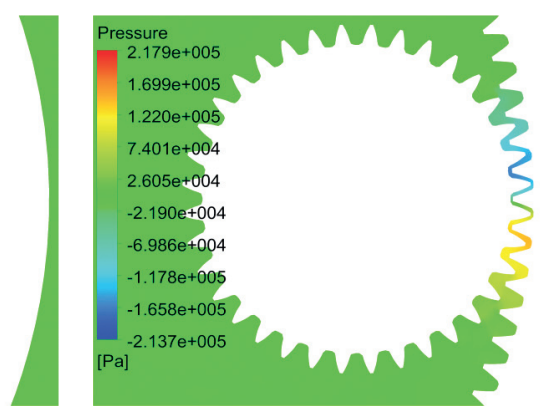

(b)

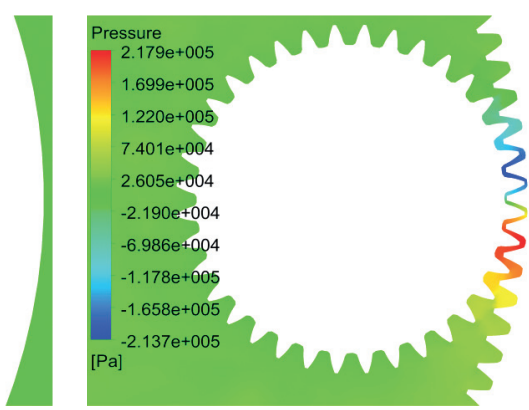

(c)

Figure 4: Pressure contours in the middle section of the meshing area of an internal gear pair: rotation speed of the pinion at (a) $2000 \mathrm{rpm}$, (b) $3000 \mathrm{rpm}$, and (c) $4000 \mathrm{rpm}$.

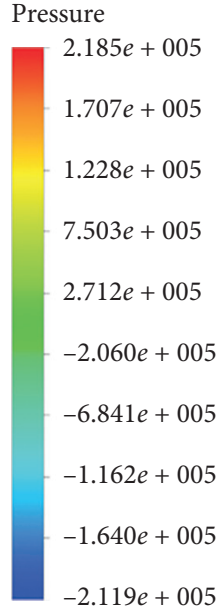

$[\mathrm{Pa}]$

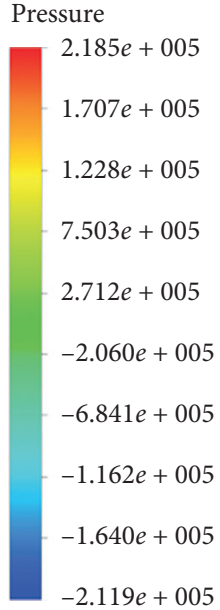

[Pa]

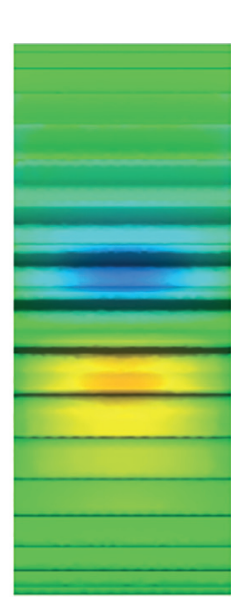

(b)

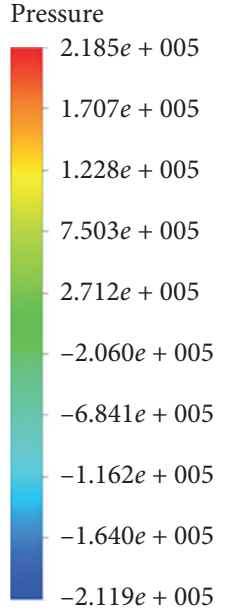

$[\mathrm{Pa}]$

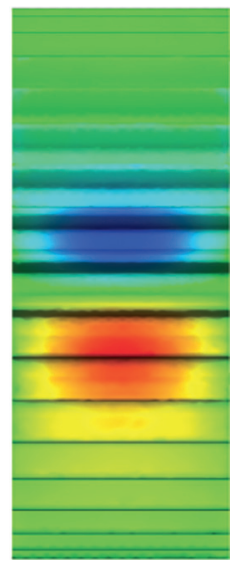

(c)

FiguRE 5: Tooth surface pressure contours of the pinion of an internal gear pair: rotation speed of the pinion at (a) $2000 \mathrm{rpm}$, (b) $3000 \mathrm{rpm}$, and (c) $4000 \mathrm{rpm}$.

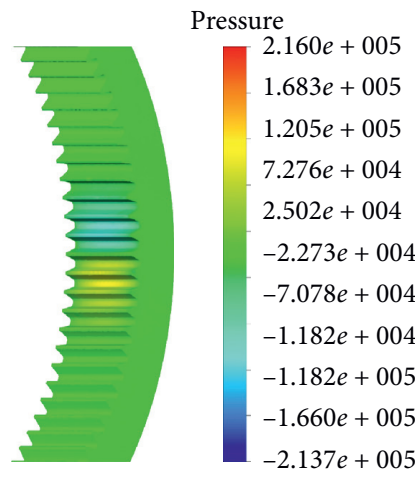

[Pa]

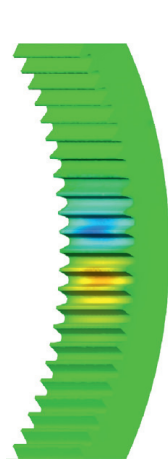

(a)

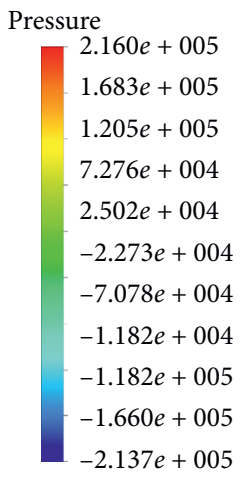

[Pa]

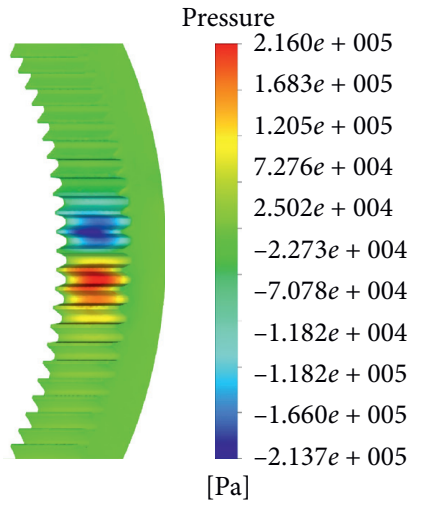

(c)

FIGURE 6: Tooth surface pressure contours of the wheel of an internal gear pair: rotation speed of the pinion at (a) $2000 \mathrm{rpm}$, (b) $3000 \mathrm{rpm}$, and (c) $4000 \mathrm{rpm}$. 


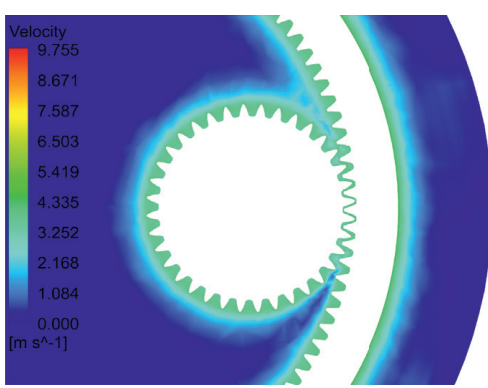

(a)

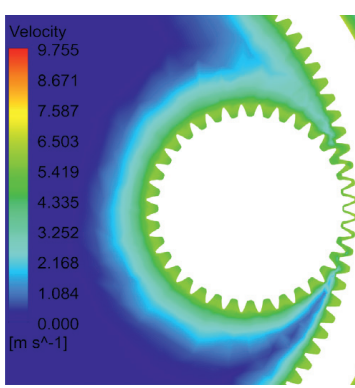

(b)

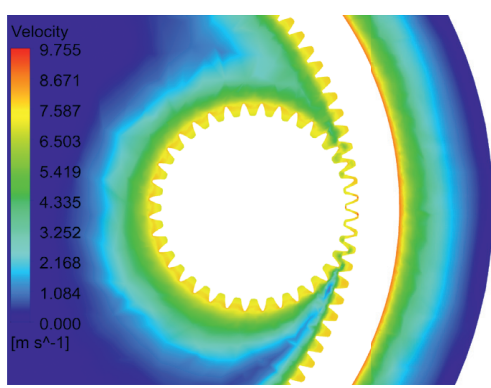

(c)

Figure 7: Velocity contours in the middle section of the meshing area of an internal gear pair: rotation speed of the pinion at (a) $2000 \mathrm{rpm}$, (b) $3000 \mathrm{rpm}$, and (c) $4000 \mathrm{rpm}$.

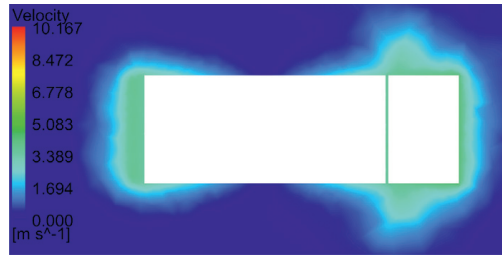

(a)

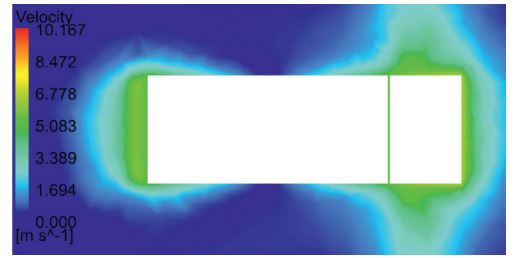

(b)

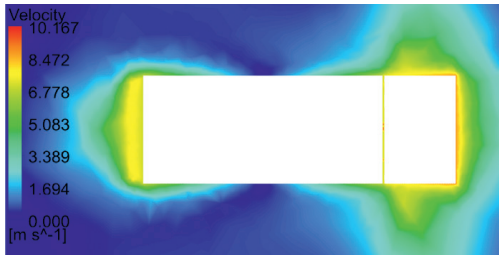

(c)

FIGURE 8: Velocity contours in the axial section of the meshing area of an internal gear pair: rotation speed of the pinion at (a) $2000 \mathrm{rpm}$, (b) $3000 \mathrm{rpm}$, and (c) $4000 \mathrm{rpm}$.

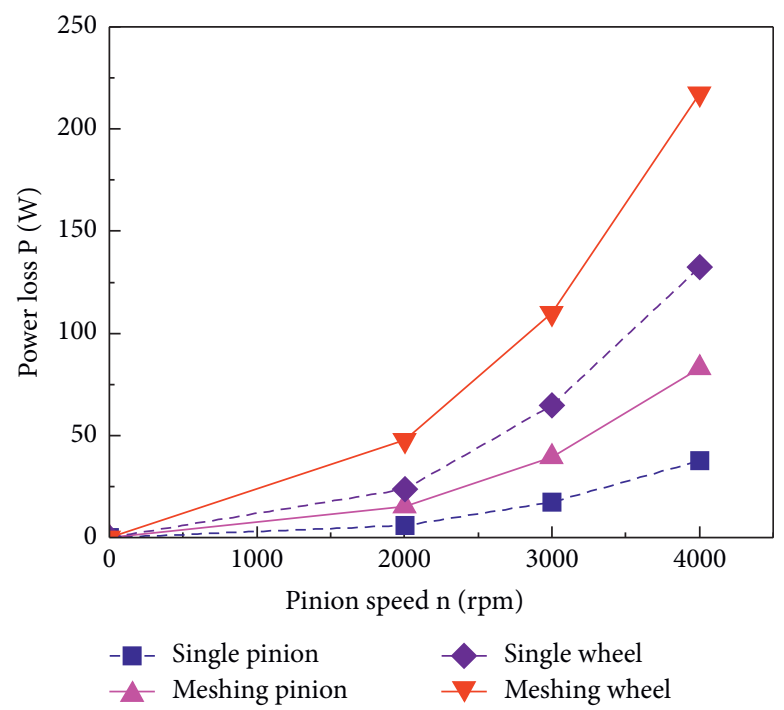

(a)

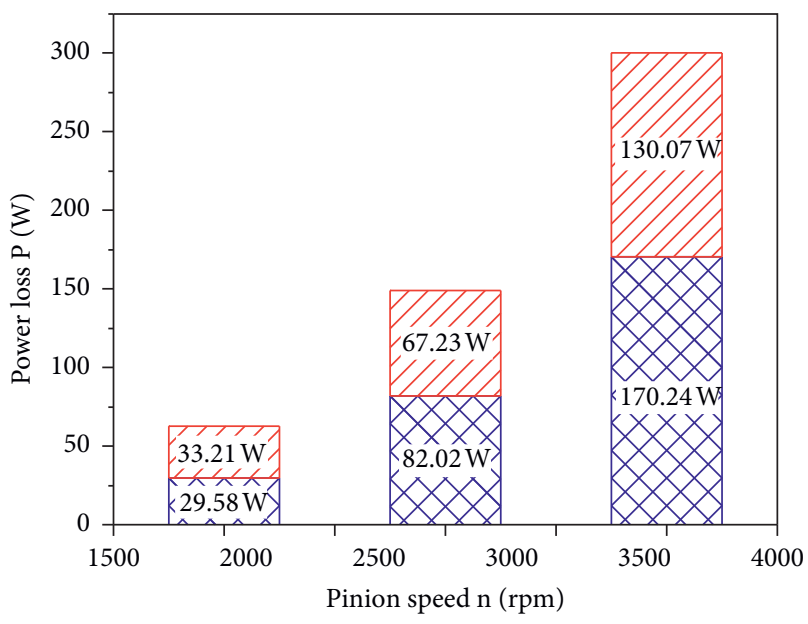

$\square$ Windage power losses ZIJ Squeezing power losses

(b)

FIGURE 9: Influence of rotation speed of the pinion on (a) the power losses of the pinion and wheel in an internal gear pair and (b) the windage and squeezing power losses of an internal gear pair.

tooth surface, with the increase of tooth width, the area of the cluster high-pressure area and low pressure area gradually increases, as shown in Figures 12 and 13.

Figures 14 and 15, respectively, show the velocity nephograms of the middle section and axial section of the meshing area when the rotation speed of the pinion of the internal gear pair is $2000 \mathrm{rpm}$ and the tooth width is $20 \mathrm{~mm}$, $25 \mathrm{~mm}$, and $30 \mathrm{~mm}$. According to the viscosity condition, as only the tooth width condition of the gear pair is changed, the flow velocity of lubricating oil near the gear pair with a different tooth width is basically unchanged, which is proved in Figure 14. However, with the increase of tooth width, more lubricating oil is stirred by the gear pair. When the tooth width is $20 \mathrm{~mm}$, the velocity disturbance at the outlet of the meshing area in the middle section is more significant than that at the inlet, as shown in Figure 14(a). However, with the increase of tooth width, the velocity disturbance at the outlet of meshing area in the middle section gradually decreases. Therefore, in the 


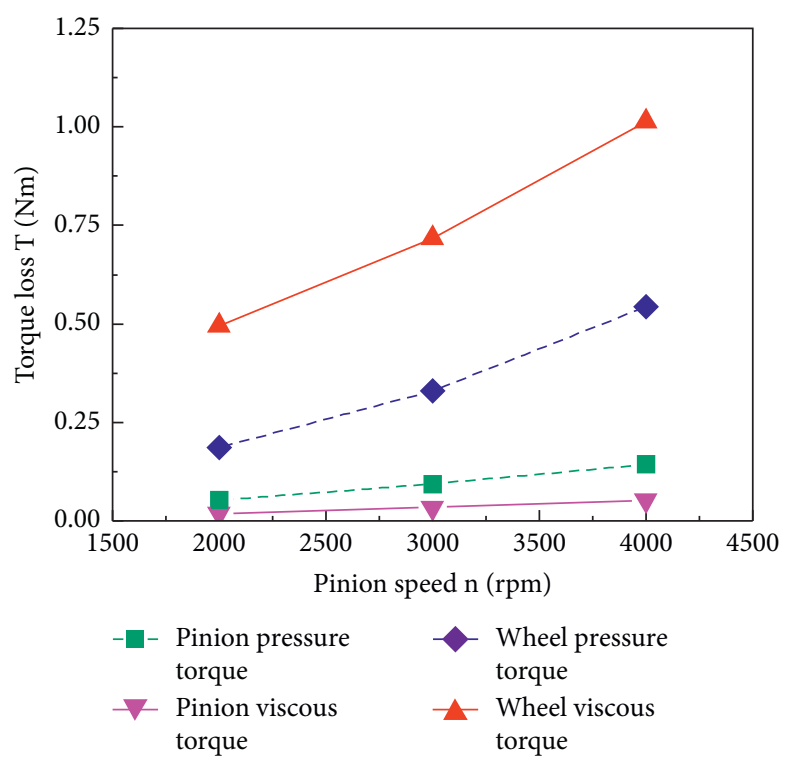

(a)

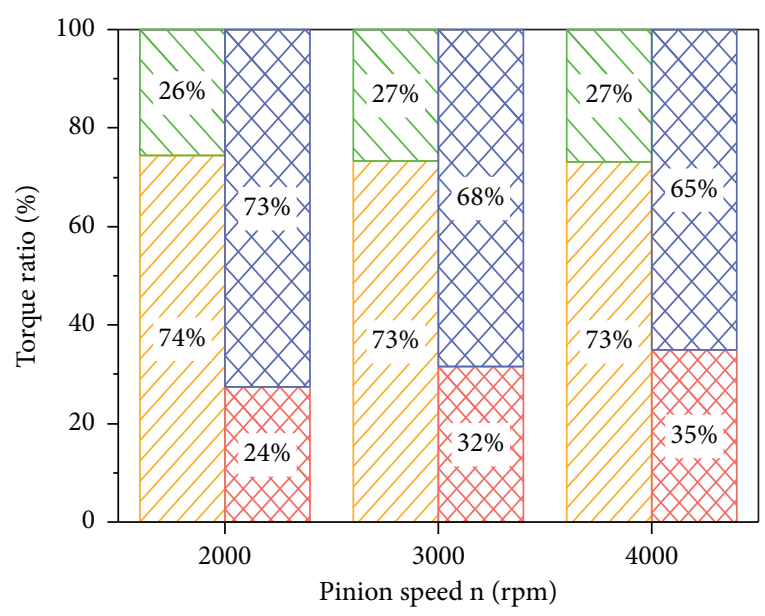

$\begin{array}{lc}\square 7 \begin{array}{l}\text { Pinion pressure } \\ \text { torque }\end{array} & \begin{array}{l}\text { Wheel pressure } \\ \text { torque }\end{array} \\ \Delta \nabla \begin{array}{l}\text { Pinion viscous } \\ \text { torque }\end{array} & \square \Delta \text { Wheel viscous } \\ \text { torque }\end{array}$

(b)

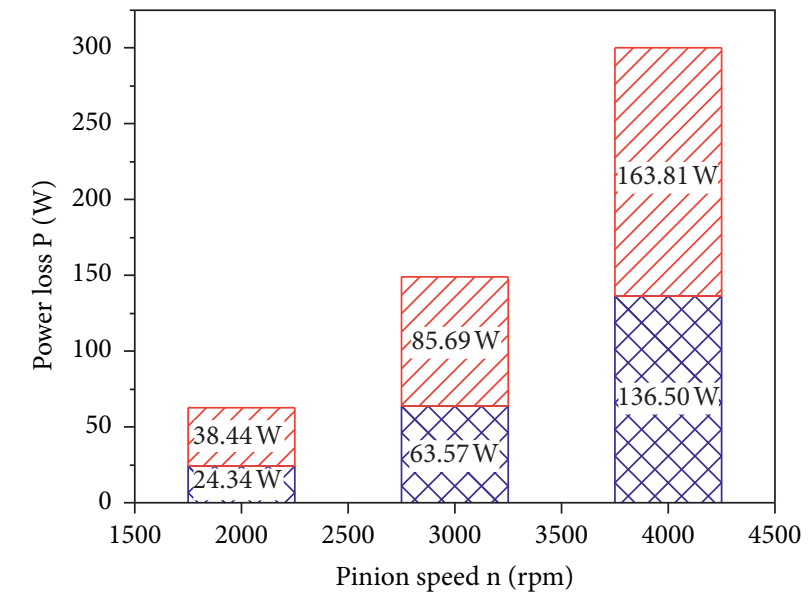

$\square$ Pressure power losses

II] Viscous power losses

(c)

FIGURE 10: Influence of rotation speed of the pinion on (a) the pressure and viscous torque loss of the pinion and wheel of the internal gear pair and (b) its contribution to the torque loss and (c) the pressure and viscous power loss of the internal gear pair.

axial direction of the meshing area, the velocity disturbance at the edge of the gear teeth is greater than that at the central position, and the axial velocity distribution rule is less affected by the tooth width, as shown in Figure 15.

When the tooth width of the gear pair is changed, the loadindependent power losses caused by an internal gear pair are still greater than the sum of the load-independent power losses caused by two single gears, as shown in Figure 16(a). The windage and squeezing power losses of the internal gear pair increase with the increase of tooth width, as shown in Figure 16(b). Under different tooth widths, the proportions of squeezing power losses in the load-independent power losses of internal gear pair are 52.89\%, 53.14\%, 55.95\%, and 64.58\%, which means that the proportion of squeezing power losses in the load-independent power losses increases with the increase of tooth width.
Figure 17 shows the variation of pressure and viscosity losses of the pinion and wheel gears in the internal gear pair with tooth width and their proportions in the torque losses and the power losses. The pressure and viscous torque losses of the pinion and wheel in the internal gear pair increase with the increase of tooth width, which is consistent with the variation trend of pressure and velocity distribution in the computational domain, as shown in Figure 17(a). In the internal gear pair, the proportions of pressure torque losses of the pinion and wheel increase with the increase of tooth width. However, the pressure torque losses are the main factor in the pinion gear, while the viscous torque losses are the main one in the wheel gear. Under the condition of each tooth width, the proportions of viscous power losses in the load-independent power losses of the internal gear pair are $61.22 \%, 51.21 \%, 49.67 \%$, and $43.07 \%$, 


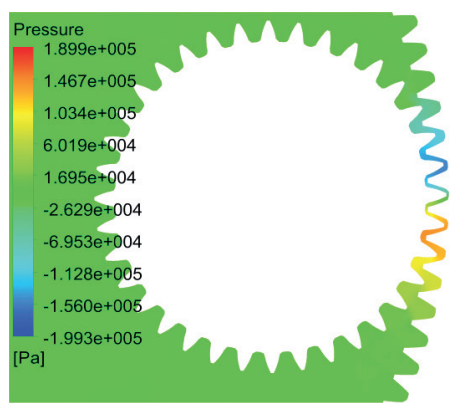

(a)
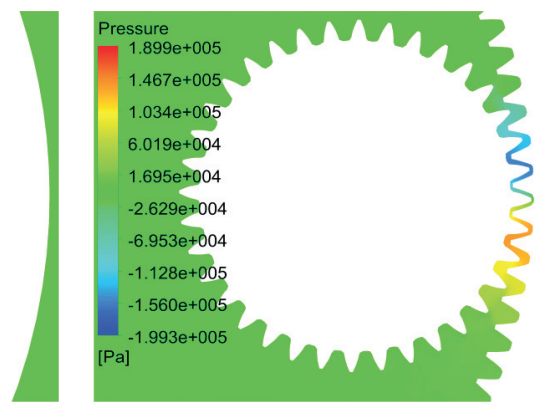

(b)
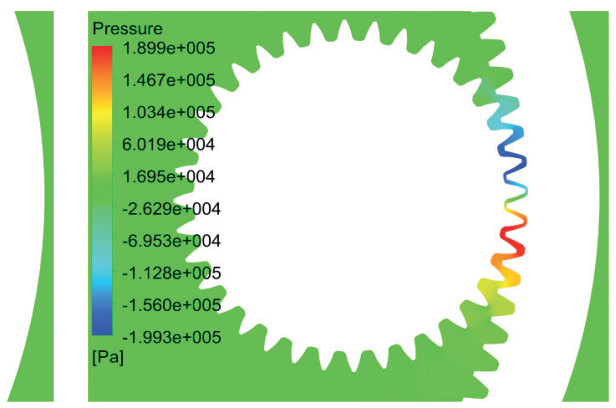

(c)

Figure 11: Pressure contours in the middle section of the meshing area of an internal gear pair: tooth width at (a) $20 \mathrm{~mm}$, (b) $25 \mathrm{~mm}$, and (c) $30 \mathrm{~mm}$.

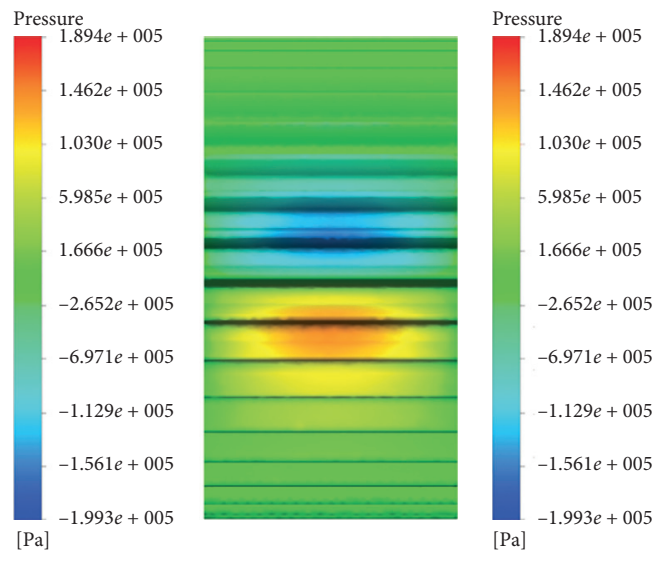

(a)

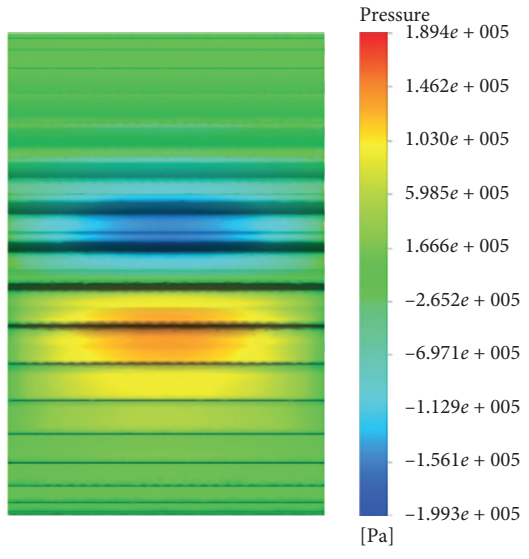

(b)

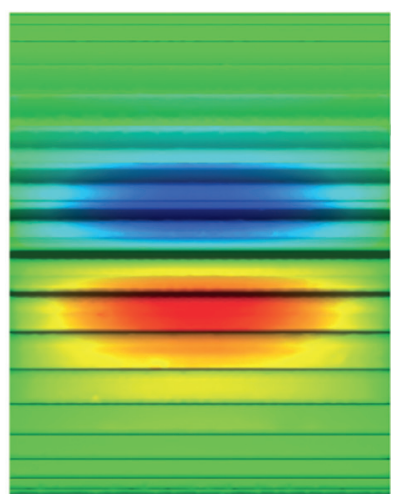

(c)

FIGURE 12: Tooth surface pressure contours of the pinion of an internal gear pair: tooth width at (a) $20 \mathrm{~mm}$, (b) $25 \mathrm{~mm}$, and (c) $30 \mathrm{~mm}$.

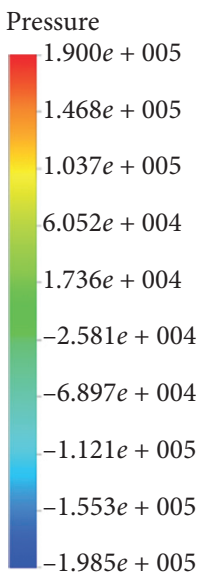

[Pa]

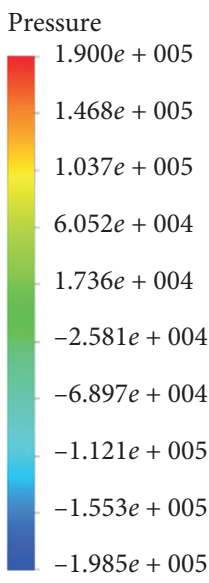

[Pa]

(a)

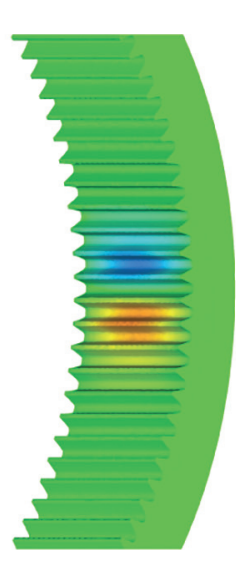

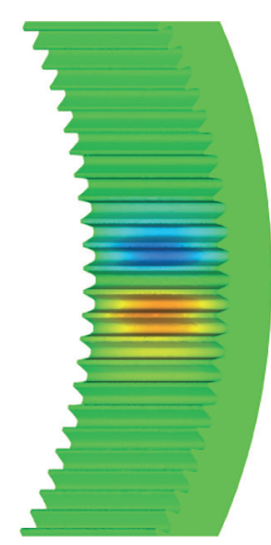

(b)

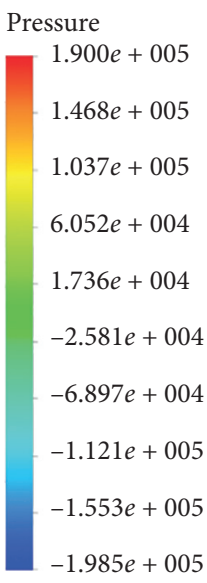

[Pa]

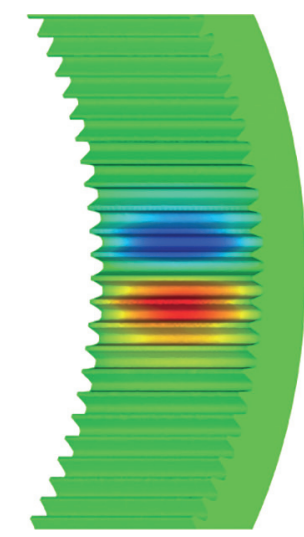

(c)

Figure 13: Tooth surface pressure contours of the wheel of an internal gear pair: tooth width at (a) $20 \mathrm{~mm}$, (b) $25 \mathrm{~mm}$, and (c) $30 \mathrm{~mm}$. 


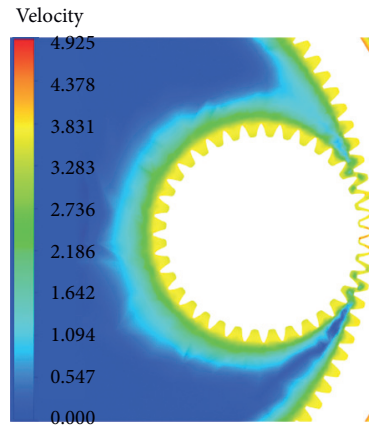

$\left[\mathrm{ms}^{-1}\right]$

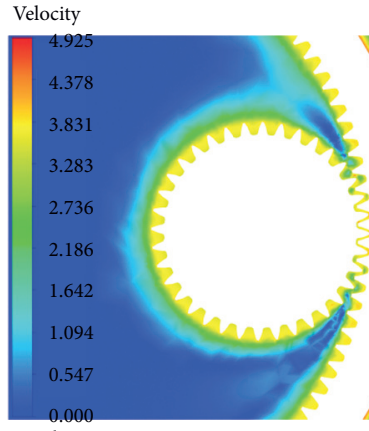

$\left[\mathrm{ms}^{-1}\right]$

(a)

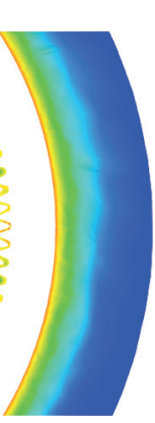

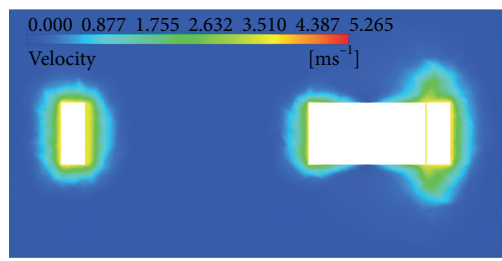

(a)

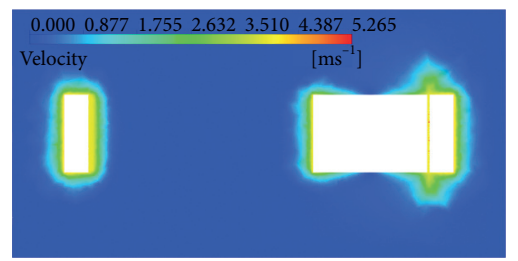

(b)

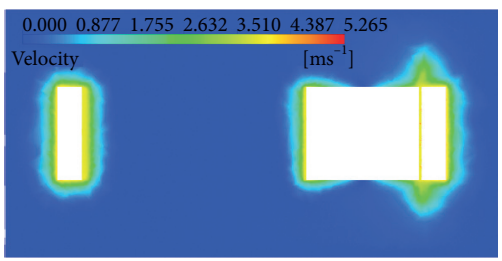

(c)

FIGURE 15: Velocity contours in the axial section of the meshing area of an internal gear pair: tooth width at (a) $20 \mathrm{~mm}$, (b) $25 \mathrm{~mm}$, and (c) $30 \mathrm{~mm}$.

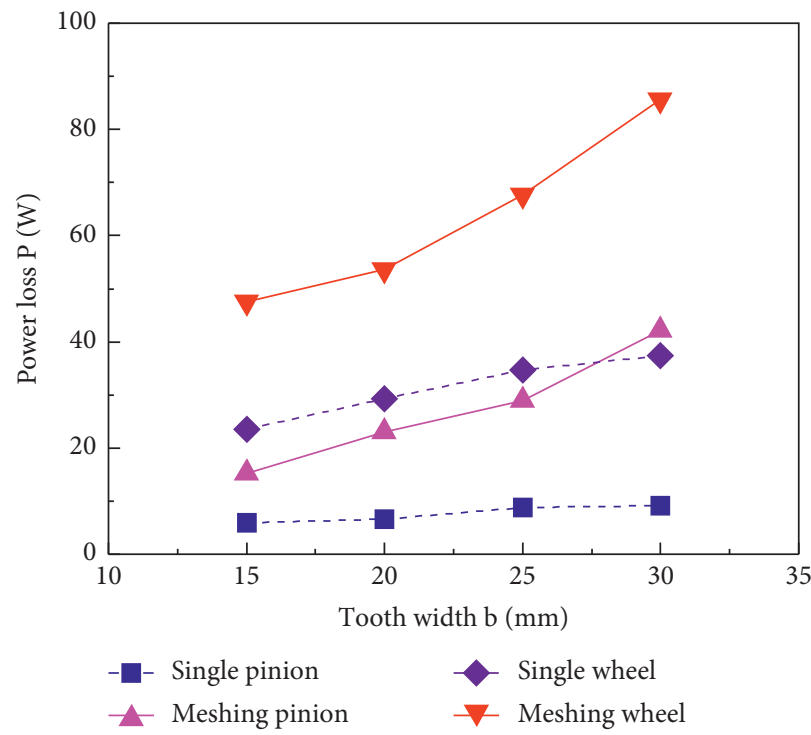

(a)

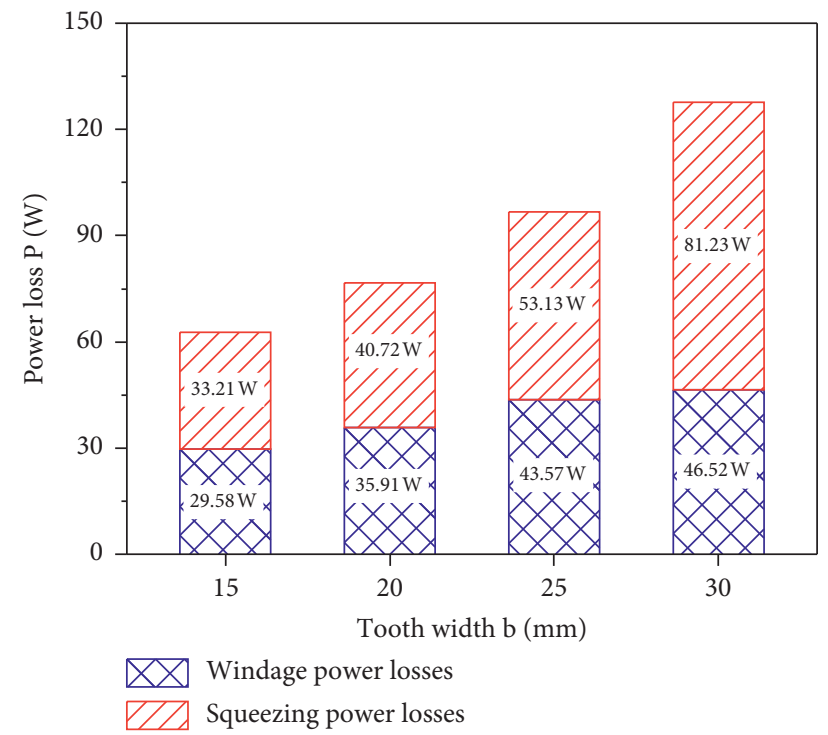

(b)

FIgURe 16: Influence of tooth width on (a) the power losses of the pinion and wheel in an internal gear pair and (b) the windage and squeezing power losses of an internal gear pair. 


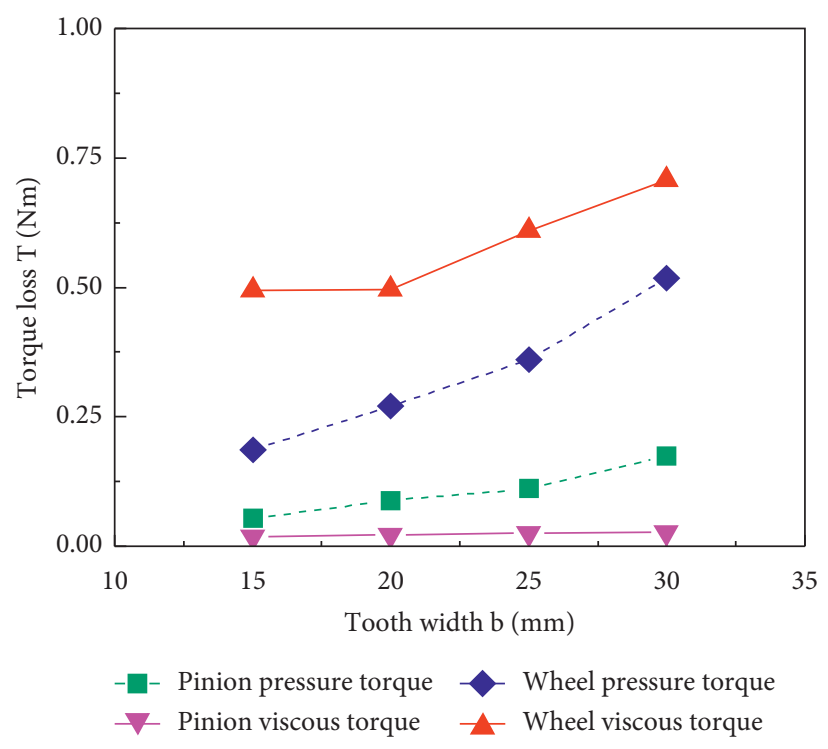

(a)

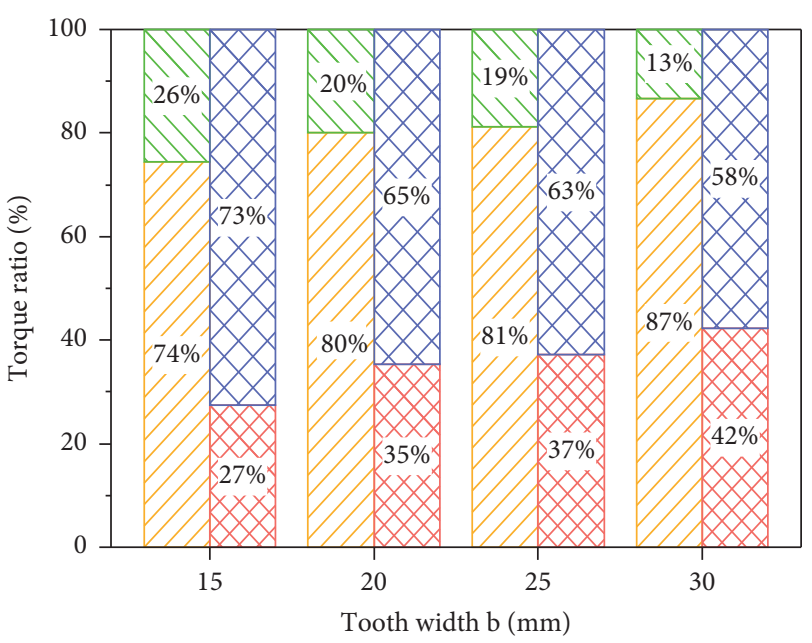

Pinion pressure torque $\mathbb{X}$ Wheel pressure torque Pinion viscous torque $\varnothing \backslash$ Wheel viscous torque

(b)

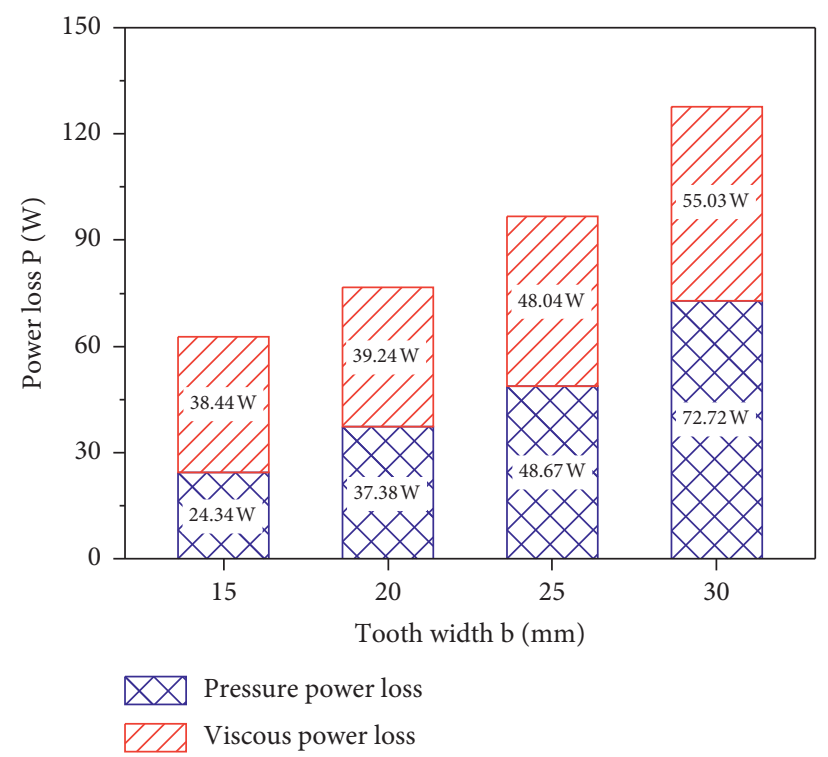

(c)

FIGURE 17: Influence of tooth width on (a) the pressure and viscous torque loss of the pinion and wheel of the internal gear pair and (b) its contribution to the torque loss and (c) the pressure and viscous power loss of the internal gear pair.

respectively, that is, the proportion of viscous power losses in load-independent power losses decreases with the increase of tooth width, as shown in Figure 17(c).

\section{Comparative Analysis of Flow Field Characteristics and Load-Independent Power Losses of External and Internal Gear Pairs}

Figures 18-20 show the distribution and variation of static pressure in the middle section of the meshing area, the tooth surface of the pinion, and the tooth surface of the wheel when the rotation speed of the pinion of the external gear pair is $2000 \mathrm{rpm}, 3000 \mathrm{rpm}$, and $4000 \mathrm{rpm}$, respectively. It can be illustrated that the pressure distribution in the meshing area of the external gear pair is similar to that of the internal gear pair. At the inlet of the meshing area, the local high-pressure area is formed due to the decrease of the fluid volume, and the local lowpressure area is formed at the outlet of the meshing area due to the increase of the fluid volume. There are also two distinct pressure peaks in the high-pressure area and the low-pressure area, and the pressure difference between the high-pressure area and the low-pressure area 


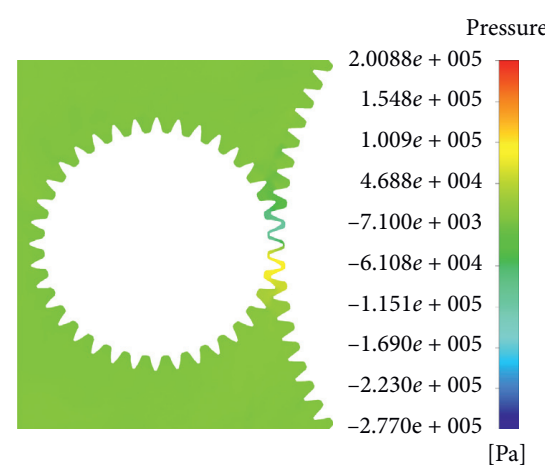

(a)

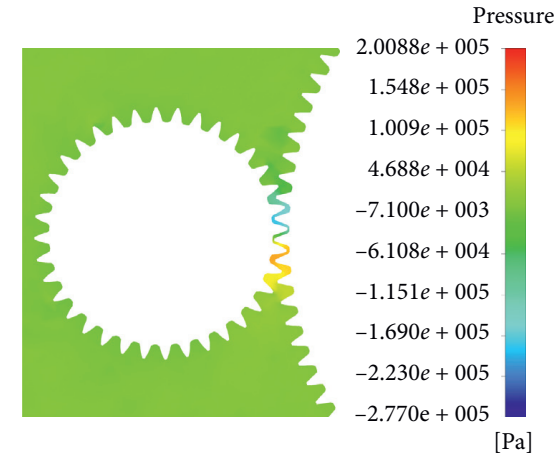

(b)

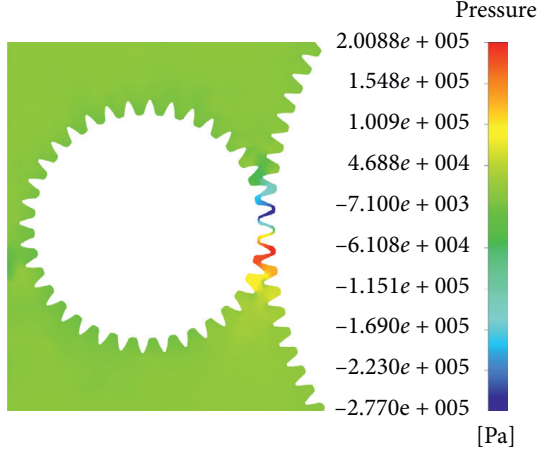

(c)

FIGURE 18: Pressure contours in the middle section of the meshing area of an external gear pair: rotation speed of pinion at (a) $2000 \mathrm{rpm}$, (b) $3000 \mathrm{rpm}$, and (c) $4000 \mathrm{rpm}$.

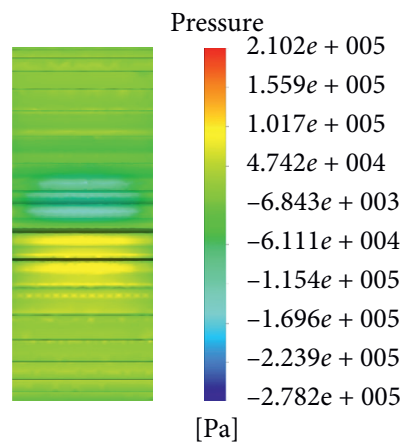

(a)

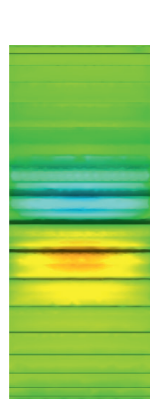

(b)

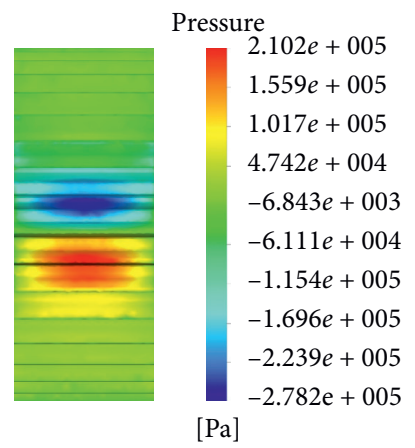

(c)

FIGURE 19: Tooth surface pressure contours of the pinion of an external gear pair: rotation speed of pinion at (a) $2000 \mathrm{rpm}$, (b) $3000 \mathrm{rpm}$, and (c) $4000 \mathrm{rpm}$.

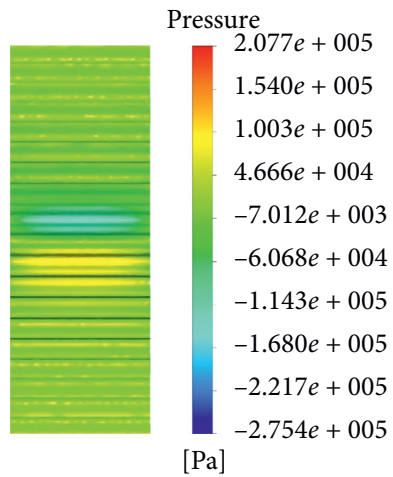

(a)

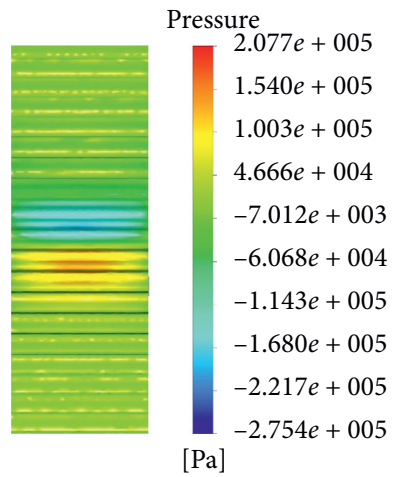

(b)

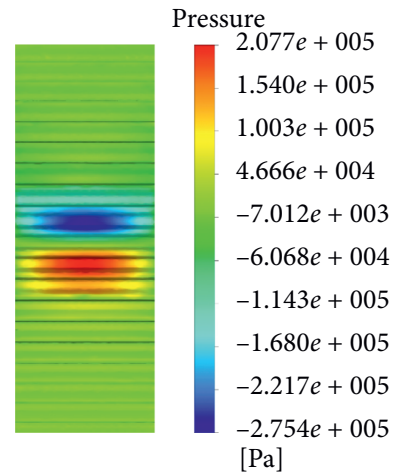

(c)

FIgURE 20: Tooth surface pressure contours of the wheel of an external gear pair: rotation speed of pinion at (a) $2000 \mathrm{rpm}$, (b) $3000 \mathrm{rpm}$, and (c) $4000 \mathrm{rpm}$.

increases with the increase of rotation speed. However, compared with the internal gear pair, the range of pressure sudden change at the inlet and outlet of the meshing area of the external gear pair is smaller.

In order to clearly observe the region of sudden pressure change, the pressure nephograms of the pinion tooth surfaces in the external and internal gear pair were expanded under $4000 \mathrm{rpm}$, as shown in Figure 21. From the figures, the length of the sudden pressure change region of the tooth surface can be observed more obviously. The length of the sudden pressure change region of the external gear pair is about 6 7 gear teeth, and the length of the sudden pressure 


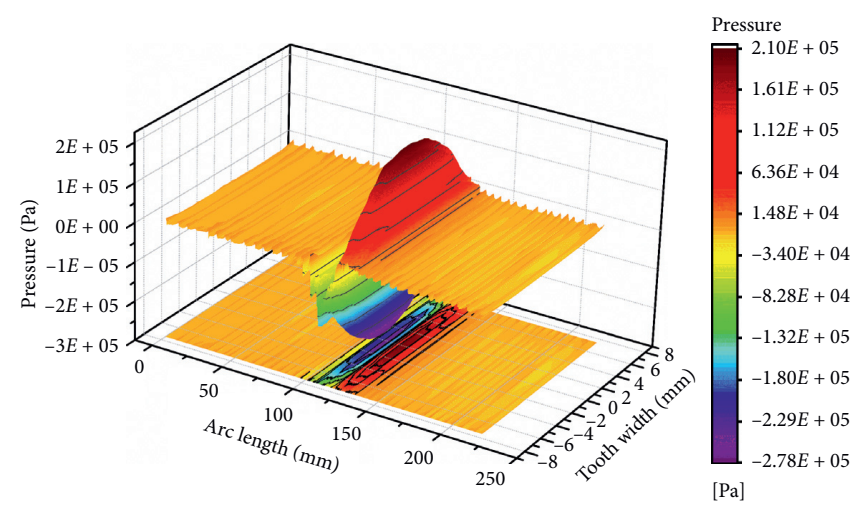

(a)

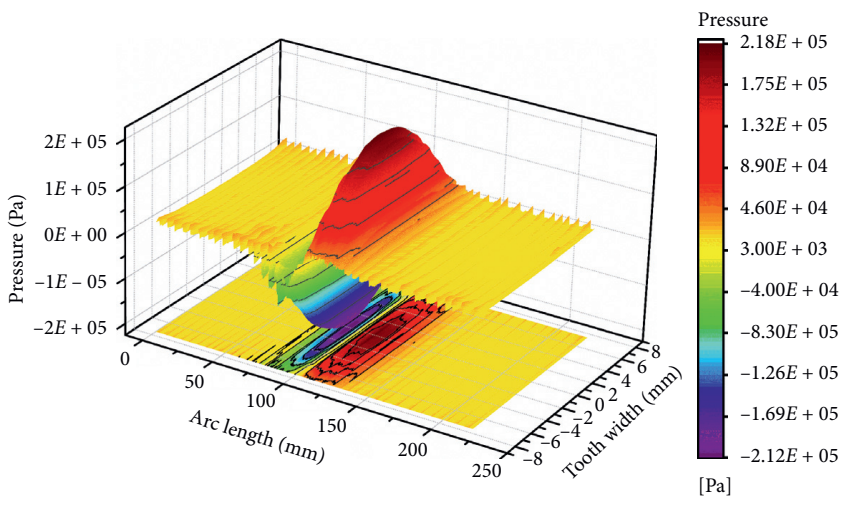

(b)

FIgURE 21: Tooth surface pressure contours of an (a) external gear pair pinion and (b) internal gear pair pinion.

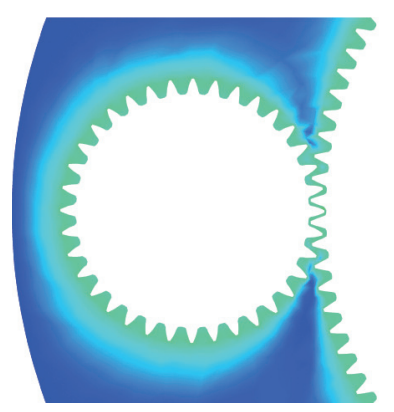

(a)

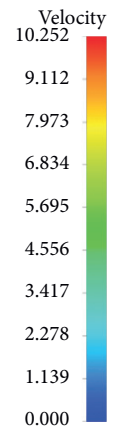

$\left[\mathrm{ms}^{-1}\right]$

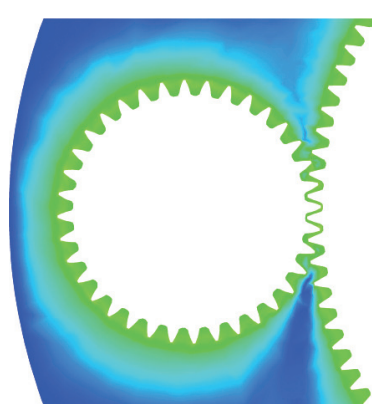

(b)

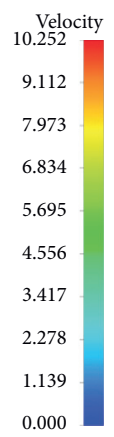

$\left[\mathrm{ms}^{-1}\right]$

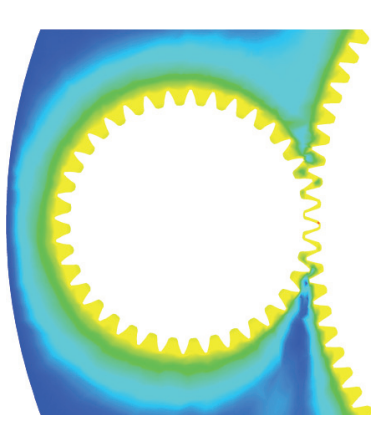

(c)

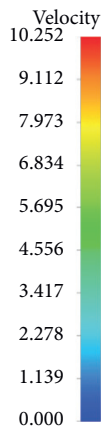

$\left[\mathrm{ms}^{-1}\right]$

FIGURE 22: Velocity contours in the middle section of the meshing area of an external gear pair: rotation speed of pinion at (a) $2000 \mathrm{rpm}$, (b) $3000 \mathrm{rpm}$, and (c) $4000 \mathrm{rpm}$.

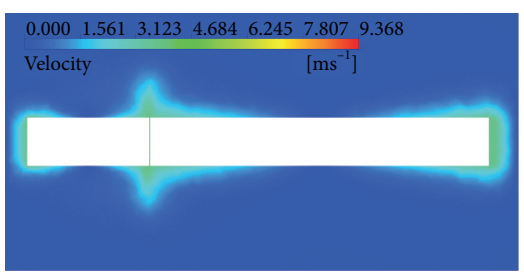

(a)

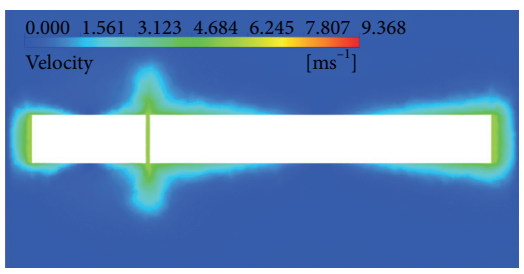

(b)

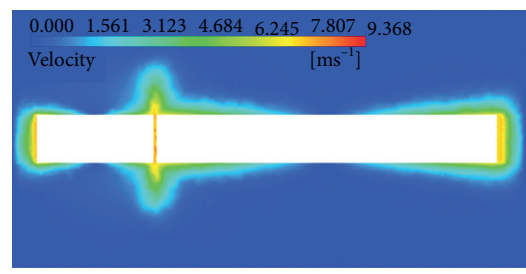

(c)

FIGURE 23: Velocity contours in the axial section of the meshing area of an external gear pair: rotation speed of pinion at (a) 2000 rpm, (b) $3000 \mathrm{rpm}$, and (c) $4000 \mathrm{rpm}$.

change region of the internal gear pair is about $8 \sim 9$ gear teeth. It can be predicted that the difference of the length of the sudden pressure change region will bring the difference of the resistance moment of the pinions.

Figures 22 and 23, respectively, show the velocity nephograms of the middle section and axial section of the meshing area when thr rotation speed of the pinion of the external meshing gear pair is $2000 \mathrm{rpm}, 3000 \mathrm{rpm}$, and $4000 \mathrm{rpm}$. Figure 22 shows that the velocity distribution in the meshing area of the external gear pair is similar to that of the internal gear pair. The velocity of lubricating oil increases with the increase of pinion speed, and the velocity of lubricating oil near the gear teeth is higher. The velocity disturbance at the meshing outlet is more significant than that at the meshing inlet, and there is also a significant axial velocity disturbance in the meshing area. The external gear pair and the internal gear pair have the same circumferential velocity, while the inner gear of the internal gear pair has the external profile, so the lubricating oil velocity near the external profile of the inner gear of the internal gear pair is higher.

As shown in Figure 24(a), the load-independent power losses caused by an external gear pair are also 


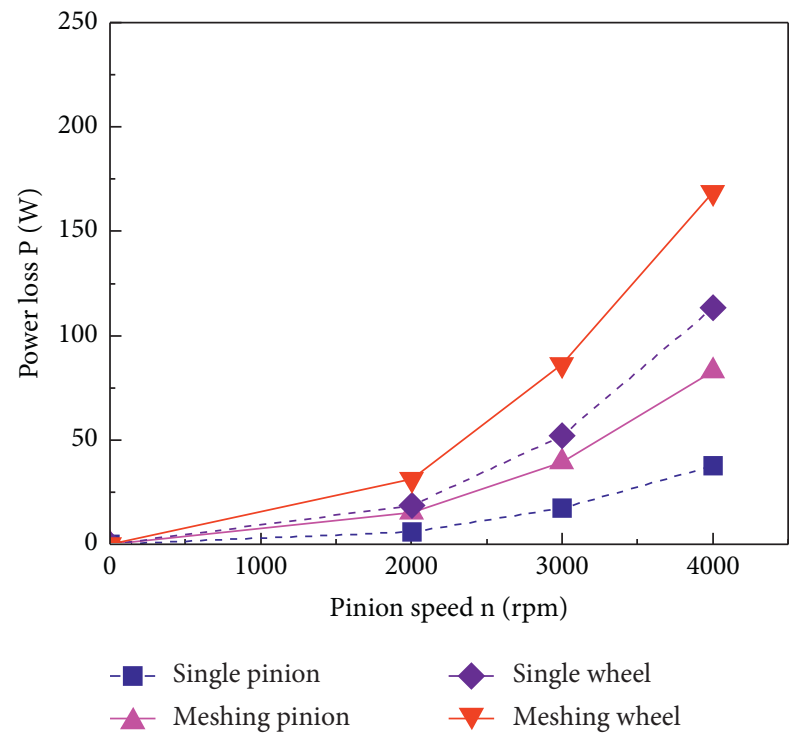

(a)

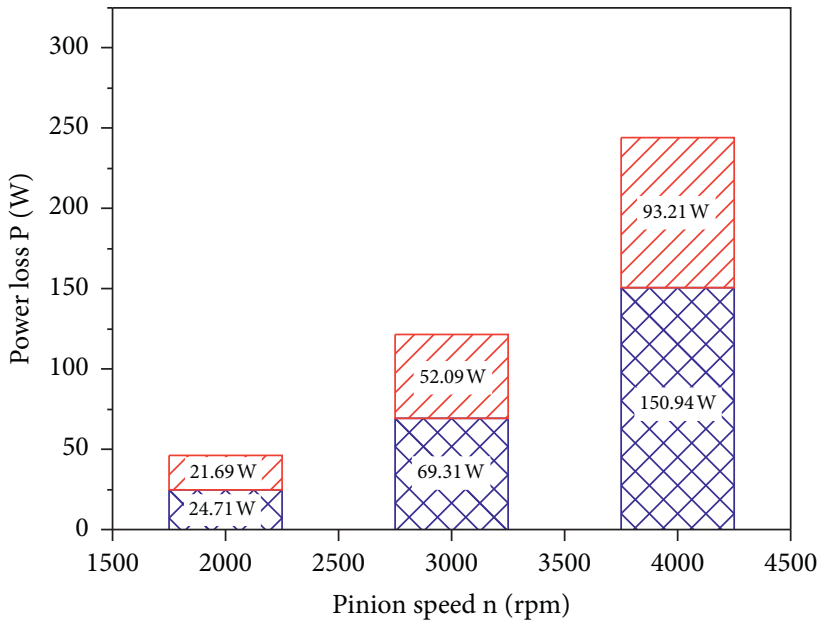

$\bowtie$ Windage power losses $\nabla / A$ squeezing power losses

(b)

Figure 24: Influence of rotation speed of the pinion on (a) the power losses of the pinion and wheel in an external gear pair and (b) the windage and squeezing power losses of an external gear pair.

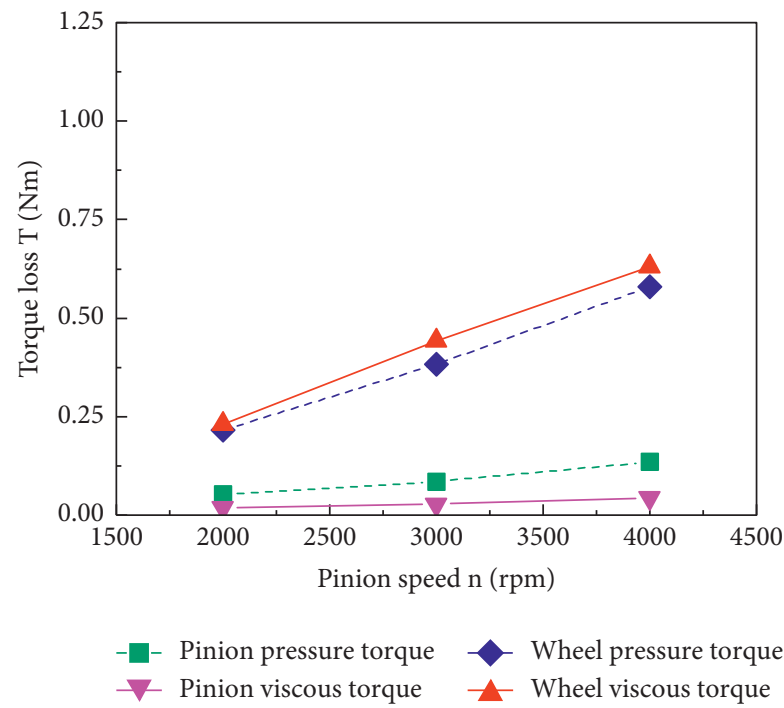

(a)

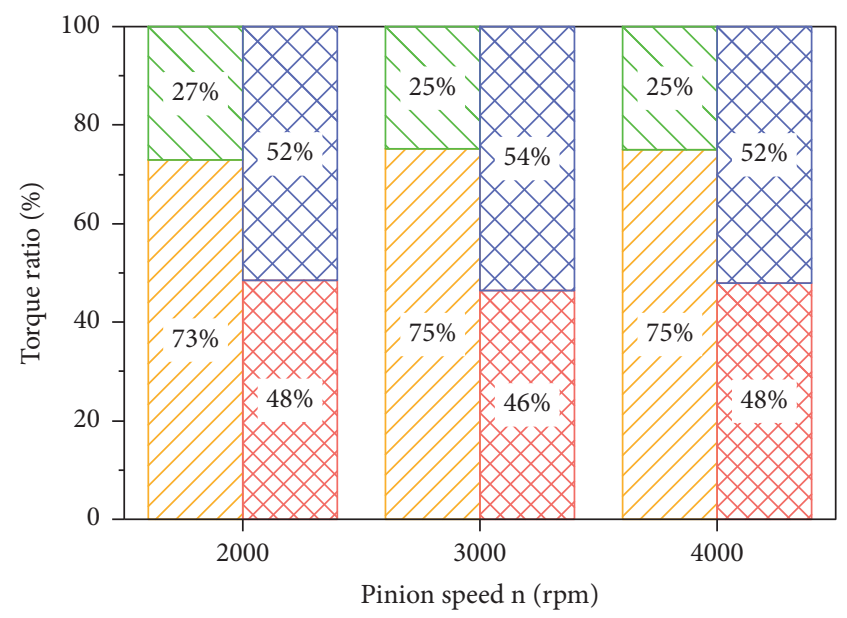

$7 /$ Pinion pressure torque $\mathbb{X}$ Wheel pressure torque $\triangle$ Pinion viscous torque $\quad \nabla X$ Wheel viscous torque

Figure 25: Continued. 


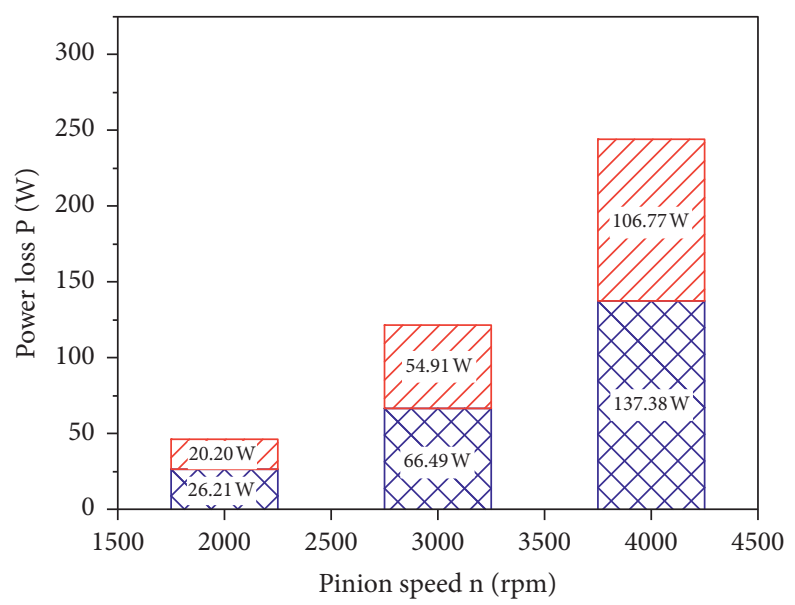

$\bigotimes$ Pressure power loss

$\nabla / \lambda$ Viscous power loss

(c)

Figure 25: Influence of rotation speed of the pinion on (a) the pressure and viscous torque loss of the pinion and wheel of the external gear pair and (b) its contribution to the torque loss and (c) the pressure and viscous power loss of the external gear pair.

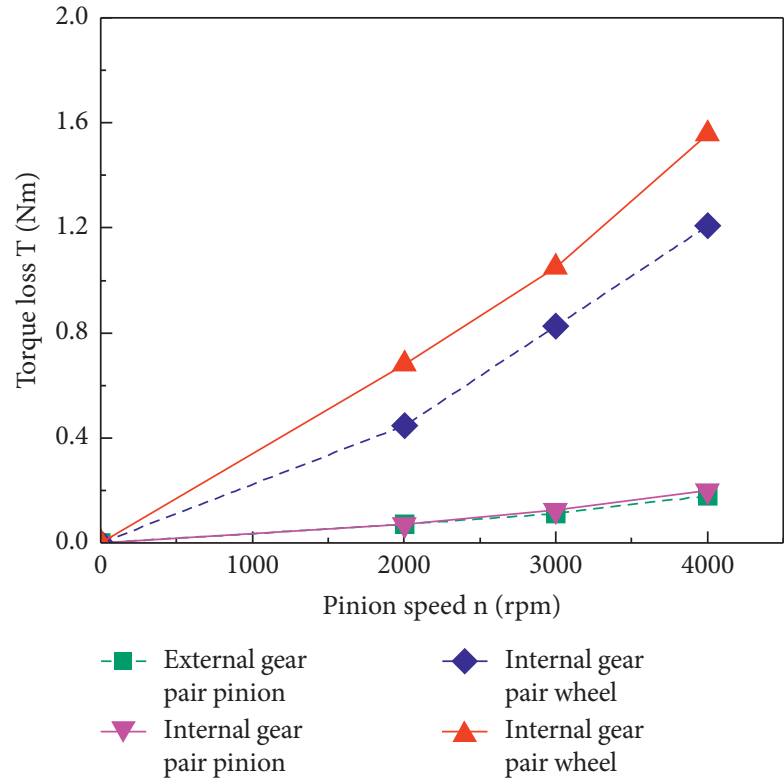

(a)

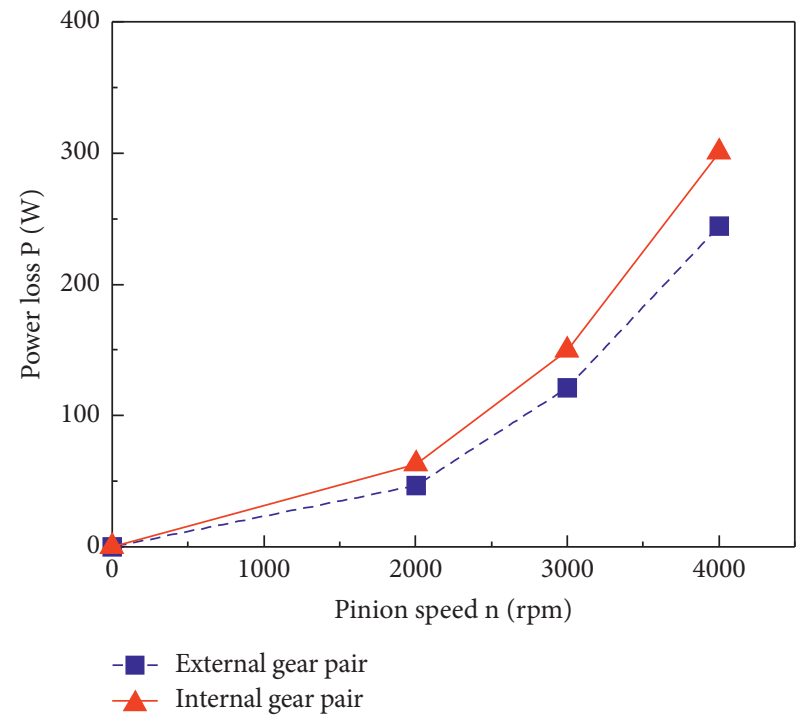

(b)

Figure 26: Comparison of (a) torque loss and (b) power loss of external and internal gear pairs.

greater than the sum of the load-independent power losses caused by two single gears, which is the same as that of the internal gear pair. Windage power losses and squeezing power losses of the external gear pair increase with the increase of rotation speed of the pinion, which is the same as that of the internal gear pair. Figure 24(b) shows the proportions of windage losses and squeezing losses in the load-independent power losses of the external gear pair. At different rotation speeds, the proportions of the squeezing power losses in the loadindependent power losses of the external gear pair are
$46.74 \%, 42.91 \%$, and $38.18 \%$, respectively, that is, the proportion of the squeezing power losses in the loadindependent power losses decreases with the increase of rotation speed. Compared with the internal gear pair, the windage losses and squeezing losses of the external gear pair are smaller than those of the internal gear pair at the same rotation speed, and the proportion of squeezing power losses in the load-independent power losses of the external gear pair is smaller.

Figure 25 shows the variation of the pressure and viscosity losses of the pinion and wheel gears in the external gear pair 


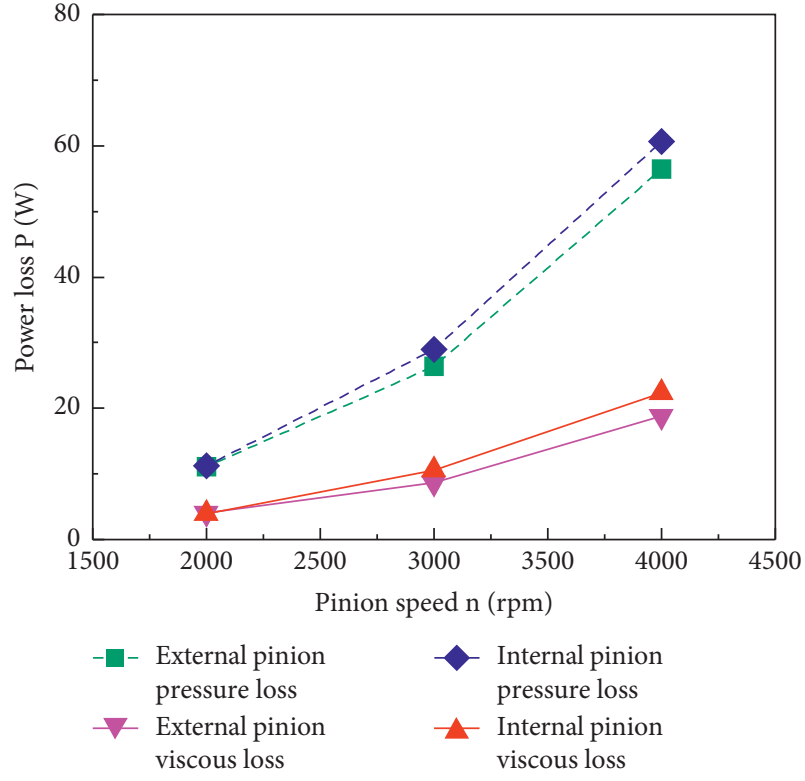

(a)

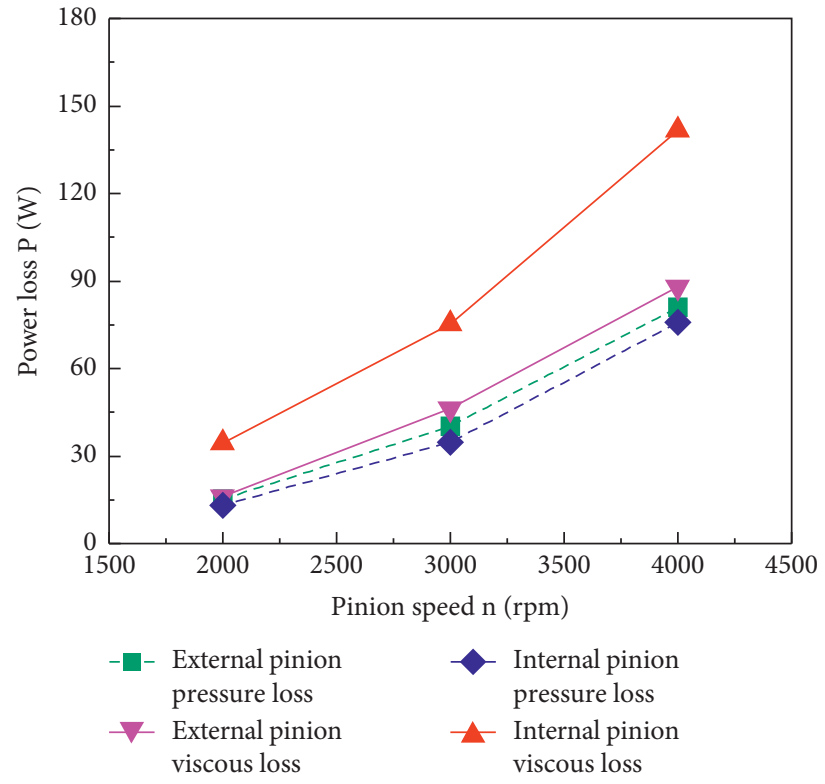

(b)

FIGURE 27: Comparison of pressure and viscous power loss between the (a) pinion and (b) wheel in external and internal gear pairs.

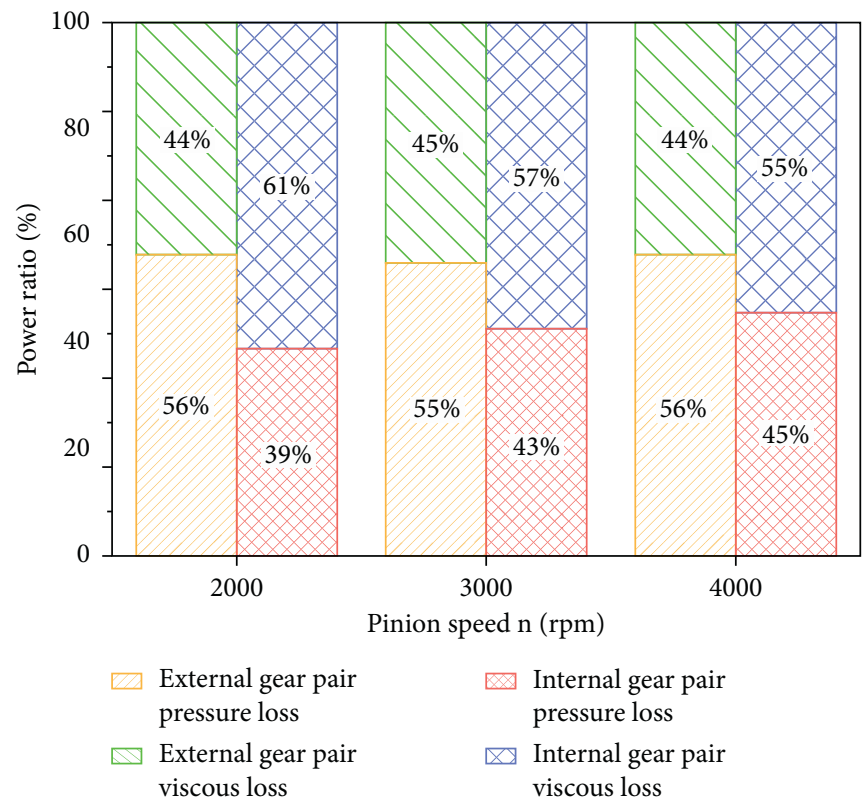

FIgURE 28: Contribution of pressure and viscosity power loss to total power loss in external and internal gear pairs.

with rotation speed of the pinion and their proportions in torque losses and the power losses. The pressure and viscous torque losses of the pinion and wheel in the external gear pair increase with the increase of rotation speed of the pinion, which is consistent with the change trend of the pressure and velocity distribution in the computational domain, as shown in Figure 25(a). In the torque losses of the pinion and wheel of the external gear pair, the proportions of pressure and viscous torque losses vary little with rotation speed. Although the circumferential speed is the same, compared with pinion, the proportion of viscous torque losses of the wheel is larger. At each rotation speed, the proportions of viscous power losses in load-independent power losses of external gear pair are $43.52 \%$, $45.23 \%$, and $43.73 \%$, which mean that the proportion of viscous power losses in load-independent power losses varies little with rotation speed. Compared with the external gear pair and the internal gear pair, it is found that the proportions of the pressure and viscous torque losses of the pinion in the two 
meshing modes are basically the same, while the proportion of the viscous torque losses of the wheel in the internal gear pair is higher.

Figure 26 shows the variation of torque losses and loadindependent power losses of external and internal gear pairs with rotation speed of the pinion. Load-independent power losses of external and internal gear pairs increase with the increase of rotation speed of the pinion, but present a nonlinear relationship. Under the same transmission ratio and number of teeth, the load-independent power losses of the internal gear pair are larger than those of the external gear pair, and the difference of the power losses increases with the increase of rotation speed of the pinion, as shown in Figure 26(b). It is found that the difference of the torque losses of the pinions in the two meshing modes is small, while that of the wheel is larger in the internal gear pair. Therefore, it can be considered that the difference of power losses between the two meshing modes mainly comes from the wheel gear, and the contribution of the pinion gear is less.

By comparing the viscosity and pressure power losses of pinion and wheel gears in external and internal gear pairs, it is found that the pressure and viscous power losses of the pinion of the internal gear pair is greater than that of the pinion of the external gear pair, but the difference is small. In the internal gear pair, the pressure power losses of the wheel are less than those of the wheel of the external gear pair, while the viscous power losses are greater than those of the wheel of the external gear pair, as shown in Figure 27. Therefore, the difference between the two meshing modes is mainly due to the viscous power losses of the wheel of the internal gear pair.

Figure 28 shows, more clearly, the proportions of pressure and viscous power losses in the load-independent power losses in external and internal gear pairs. It can be illustrated that the proportions of pressure and viscous power losses in the load-independent power losses of external gear pair vary little with rotation speed, and the proportion of pressure power losses in the load-independent power losses is larger. However, the proportion of viscous power losses in the loadindependent power losses of internal gear pair decreases with the increase of rotation speed. However, under the current rotation speed condition, the viscous power losses are still in the dominant position. The pressure power losses of the external gear pair are greater than those of the internal gear pair, and the viscous power losses of the internal gear pair are greater than that of the external gear pair, as shown in Figures 10(c) and 25(c). Therefore, the difference of power losses between the two meshing modes mainly comes from the viscous power losses, and they are viscous power losses of the wheel gear. According to the analysis of the pressure field and the velocity field, the reason for the difference of power losses is the meshing mode and the special structure of the wheel gear of the internal gear pair.

\section{Conclusions}

Based on the computational fluid dynamics method, this paper establishes the simulation models of internal and external gear pairs, analyzes the influence of rotation speed and tooth width on the flow field characteristics and the load-independent power losses of internal gear pair, and compares and analyzes the difference between the flow field characteristics and the load-independent power losses between the external and internal gear pairs. The following conclusions have been drawn from this study:

(1) In the meshing process of the gear pair, the pressure change area suddenly appears in the meshing area. The higher the rotation speed is, the larger the tooth width is and the more intense the sudden pressure change is. The velocity of lubricating oil in the computational domain increases with the increase of rotation speed, and the lubricating oil moving at high speed is mainly concentrated in the meshing area and near the gear teeth. When the rotation speed is the same, the lubricating oil near the external profile of the wheel has a higher flow velocity due to the external profile of the wheel in the internal gear pair, so it will be subject to greater viscous resistance.

(2) The load-independent power losses of the internal gear pair increase with the increase of rotation speed and tooth width, but present a nonlinear relationship. In the case of the same rotation speed, transmission ratio, and number of teeth, compared with the external gear pair, the load-independent power losses of the internal gear pair are greater, and the additional power losses are mainly from the wheel gear, and the contribution of the pinion gear is relatively small. Therefore, the external gear pair has more advantages than the internal gear pair in controlling the load-independent power losses.

(3) The windage losses and squeezing losses of the internal gear pair increase with the increase of rotation speed and tooth width, but the proportion of squeezing losses in the load-independent power losses decreases with the increase of rotation speed and increases with the increase of tooth width. At the same rotation speed, transmission ratio, and number of teeth, the windage losses and squeezing losses of the external gear pair are less than those of the internal gear pair, and the proportion of the squeezing losses of the external gear pair in the load-independent power losses is smaller.

(4) With the increase of rotation speed and tooth width, pressure power losses and viscous power losses of the internal gear pair increase, but the proportion of viscous power losses decreases. The pressure and viscous power losses of the external gear pair increase with the increase of rotation speed, but the proportions of viscous power losses and pressure power losses are basically stable. In the current rotation speed range, the proportion of pressure power losses in the load-independent power losses in the external gear pair is higher, and that of viscous power losses in the load-independent power losses in the internal gear pair is higher. The difference of loadindependent power losses between the two meshing 
modes is mainly due to the viscous power losses of the internal gear pair. The reason for the difference lies in the meshing mode and the special structure of the wheel of the internal gear pair.

\section{Abbreviations}

$\begin{array}{ll}\mathrm{a}: & \text { Center distance } \\ b: & \text { Tooth width } \\ d_{a}: & \text { Tip diameter } \\ f_{i}: & \text { External forces } \\ \mathbf{F}_{\mathbf{p}}: & \text { Pressure force vector } \\ \mathbf{F}_{\mathbf{v}}: & \text { Viscous force vector } \\ i: & \text { Direction index } \\ j: & \text { Direction index } \\ m: & \text { Module } \\ \mathbf{M}: & \text { Resistance moment vector } \\ p: & \text { Pressure } \\ P_{\mathrm{VB}}: & \text { Load-dependent power losses of bearings } \\ P_{\mathrm{VD} 0}: & \text { Load-independent power losses of seals } \\ P_{\mathrm{VG}}: & \text { Load-dependent power losses of gears } \\ P_{\mathrm{VG} 0}: & \text { Load-independent power losses of gears } \\ P_{\mathrm{VG} 0}: & \text { Load-independent power losses of bearings } \\ P_{\mathrm{VG} 0, C}: & \text { Churning power losses } \\ P_{\mathrm{VG}, S}: & \text { Squeezing/pocketing power losses } \\ P_{\mathrm{VG}, W}: & \text { Windage power losses } \\ P_{\mathrm{VX}}: & \text { Other general power losses } \\ \mathbf{r}: & \text { Distance vector } \\ u_{i}: & \text { Velocity component } \\ x_{i}: & \text { Cartesian coordinate } \\ z: & \text { Number of teeth } \\ \alpha_{n}: & \text { Pressure angle } \\ \mu: & \text { Viscosity } \\ \mu_{t}: & \text { Eddy viscosity } \\ \nu: & \text { Kinematic viscosity } \\ \rho: & \text { Density } \\ \boldsymbol{\omega}: & \text { Angular velocity vector } \\ & \end{array}$

\section{Data Availability}

The data used to support the findings of this study are included within the article.

\section{Conflicts of Interest}

The authors declare that there are no conflicts of interest.

\section{Acknowledgments}

This work was supported by the Key Research and Development Project of China (Grant no. 2017YFC0603000), the National Natural Science Fund of China (Grant no. 51974170), National Natural Science Fund of Shandong Province (Grant no. ZR2019MEE067), and Key Research and Development Project of Shandong Province (Grant no. ZR 2018GGX103027).

\section{References}

[1] A. Kahraman, D. R. Hilty, and A. Singh, "An experimental investigation of spin power losses of a planetary gear set," Mechanism and Machine Theory, vol. 86, pp. 48-61, 2015.

[2] G. Niemann and H. Winter, Maschinenelemente Band 2: Getriebe Allgemein, Zahnradgetriebe-Grundlagen, SpringerVerlag, Berlin, Germany, 1983.

[3] F. Concli, E. Conrado, and C. Gorla, "Analysis of power losses in an industrial planetary speed reducer: measurements and computational fluid dynamics calculations," Proceedings of the Institution of Mechanical Engineers, Part J: Journal of Engineering Tribology, vol. 228, no. 1, pp. 11-21, 2014.

[4] W. Mauz, Hydraulische Verluste von Stirnradgetrieben bei Umfangsgeschwindigkeiten bis $60 \mathrm{~m} / \mathrm{s}$, Universität Stuttgart, Stuttgart, Germany, 1987.

[5] R. Boness, "Churning losses of discs and gears running partially submerged in oil," in Proceedings of the ASME International Power Transmission and Gearing Conference, pp. 255-359, Anaheim, CA, USA, August 1989.

[6] B.-R. Höhn, K. Michaelis, and H.-P. Otto, "Influence of immersion depth of dip lubricated gears on power loss, bulk temperature and scuffing load carrying capacity," International Journal of Mechanics and Materials in Design, vol. 4, no. 2, pp. 145-156, 2008.

[7] S. Seetharaman and A. Kahraman, "Load-independent spin power losses of a spur gear pair: model formulation[J]," Journal of Tribology, vol. 131, no. 2, pp. 1-11, 2009.

[8] S. Seetharaman, A. Kahraman, M. D. Moorhead et al., "Oil churning power losses of a gear pair: experiments and model validation," Journal of Tribology, vol. 131, no. 2, pp. 1-10, 2009.

[9] C. Changenet, G. Leprince, F. Ville et al., "A note on flow regimes and churning loss modeling," Journal of Mechanical Design, Transactions of the ASME, vol. 133, no. 12, 2011.

[10] C. Changenet and P. Velex, "A model for the prediction of churning losses in geared transmissions-preliminary results," Journal of Mechanical Design, vol. 129, no. 1, pp. 128-133, 2007.

[11] T. Schaffner, H. Allmaier, J. Girstmair, F. Reich, and O. Tangasawi, "Investigating the efficiency of automotive manual gearboxes by experiment and simulation," Proceedings of the Institution of Mechanical Engineers, Part K: Journal of Multi-Body Dynamics, vol. 228, no. 4, pp. 341-354, 2014.

[12] A. Neurouth, C. Changenet, F. Ville et al., "Experimental investigations to use splash lubrication for high-speed gears," Journal of Tribology-Transactions of the ASME, vol. 139, no. 6, p. 7, 2017.

[13] C. Gorla, F. Concli, K. Stahl et al., "CFD simulations of splash losses of a gearbox," Advances in Tribology, vol. 2012, pp. 1-10, 2012.

[14] C. Gorla, F. Concli, K. Stahl et al., "Hydraulic losses of a gearbox: CFD analysis and experiments," Tribology International, vol. 66, pp. 337-344, 2013.

[15] F. Concli, C. Gorla, A. Della Torre, and G. Montenegro, "Churning power losses of ordinary gears: a new approach based on the internal fluid dynamics simulations," Lubrication Science, vol. 27, no. 5, pp. 313-326, 2015.

[16] F. Concli and C. Gorla, "Numerical modeling of the power losses in geared transmissions: windage, churning and cavitation simulations with a new integrated approach that drastically reduces the computational effort," Tribology International, vol. 103, pp. 58-68, 2016.

[17] F. Concli, C. Gorla, A. Della Torre, and G. Montenegro, "Windage power losses of ordinary gears: different CFD 
approaches aimed to the reduction of the computational effort," Lubricants, vol. 2, no. 4, pp. 162-176, 2014.

[18] W. Liang, K. Liu, and Y. Cui, "Theoretical calculations and experimental study of spur gears churning power loss based on finite element analysis," Engineering Mechanics, vol. 33, no. 5, pp. 220-226, 2016.

[19] W. Liang, K. Liu, and Y. Cui, "Calculation and experimental verification of helical gear churning power loss based on finite element analysis," China Mechanical Engineering, vol. 25, no. 18 , pp. $2510-2515,2014$.

[20] H. Liu, T. Jurkschat, T. Lohner, and K. Stahl, "Determination of oil distribution and churning power loss of gearboxes by finite volume CFD method," Tribology International, vol. 109, pp. 346-354, 2017.

[21] X. Hu, P. Li, and M. Wu, "Influence of the dynamic motion of a splash-lubricated gearbox on churning power losses[J]," Energies, vol. 12, no. 17, 2019.

[22] Y. Dai, F. Ma, X. Zhu et al., "Numerical simulation investigation on the windage power loss of a high-speed face gear drive," Energies, vol. 12, no. 11, 2019.

[23] F. Concli, "Thermal and efficiency characterization of a lowbacklash planetary gearbox: an integrated numerical-analytical prediction model and its experimental validation," Proceedings of the Institution of Mechanical Engineers, Part J: Journal of Engineering Tribology, vol. 230, no. 8, pp. 996-1005, 2016.

[24] F. Concli and C. Gorla, "Numerical modeling of the churning power losses in planetary gearboxes: an innovative partitioning-based meshing methodology for the application of a computational effort reduction strategy to complex gearbox configurations," Lubrication Science, vol. 29, no. 7, pp. $455-474,2017$.

[25] S. Mo, Z. Zou, Z. Feng, H. Dang, H. Gao, and X. Cao, "Research on lubrication characteristics of asymmetric helical gear based on CFD method," Lubrication Science, vol. 32, no. 6, pp. 309-320, 2020.

[26] F. Concli and C. Gorla, "Windage, churning and pocketing power losses of gears: different modeling approaches for different goals," Forschung im Ingenieurwesen, vol. 80, no. 3-4, pp. 85-99, 2016.

[27] E. Burberi, T. Fondelli, A. Andreini et al., "CFD simulations of a meshing gear pair," in Proceedings of the ASME Turbo Expo 2016: Turbomachinery Technical Conference and Exposition, International Gas Turbine Institute, Seoul, South Korea, June 2016.

[28] Q. Peng, L. Gui, and Z. Fan, "Gear splash lubrication numerical simulation and validation based on teeth-face-moving method," Transactions of the Chinese Society of Agricultural Engineering, vol. 31, no. 10, pp. 51-56, 2015. 